\title{
Public Health Reports
} Vol. 63 - MARCH 19, 1948 №. 12

Printed With the Approval of the Bureau of the Budget as Required by Rule 42 of the Joint Committee on Printing

\section{ACTION OF STREPTOMYCIN IN EXPERIMENTAL INFECTION WITH Q FEVER ${ }^{1}$}

By Robert J. Huebner, Sr. Assistant Surgeon, George A. Hottle, Sr. Assistant Scientist, and Eleanor B. Robinson, Laboratory Technician, United States Public Health Service.

Reports of recent outbreaks of $\mathrm{Q}$ fever in the United States $(1,2)$ as well as in other parts of the world $(3,4,5,6)$ have focused attention on the need for a specific therapy. Streptomycin has been found to exercise rickettsiostatic action upon the causative organisms of other rickettsial diseases such as epidemic typhus, endemic typhus, Rocky Mountain spotted fever, and rickettsialpox $(7,8)$. The following is a report of the rickettsiostatic activity of streptomycin in experimental infection with $\mathbf{Q}$ fever in embryonated eggs and guinea pigs.

Action of streptomycin on growth of Rickettsia burneti in the yolksac.-Italian (Henzerling) and American (Dyer) strains of $R$. burneti were used in the experiments. Solutions of crystalline streptomycin (200 mgm/cc.), obtained from the Pure Food and Drug Administration through the courtesy of Dr. Henry Welch, were used throughout. The streptomycin contents of the basic solutions were confirmed by a standard method (9). Specified amounts of streptomycin contained in 0.5 cc. of saline were inoculated into the yolk sacs of 7-day-old embryonated eggs less than 10 minutes prior to inoculation of the specified dilutions of infectious suspensions with the exception that control eggs received normal saline instead of streptomycin (table 1). The eggs were candled each morning and all embryos dying within 72 hours of incubation were discarded.

Eggs which in subsequent candling revealed dead or moribund embryos were opened and yolk sac films were stained by Machiavello's technique and examined for rickettsiae. The data in table 1 indicate that both strains of $R$. burneti were suppressed in their growth and that the average life span of the treated embryo was significantly

\footnotetext{
1 From the Division of Infections Diseases, National Institute of Health, Bethesda, Md.
} 
है

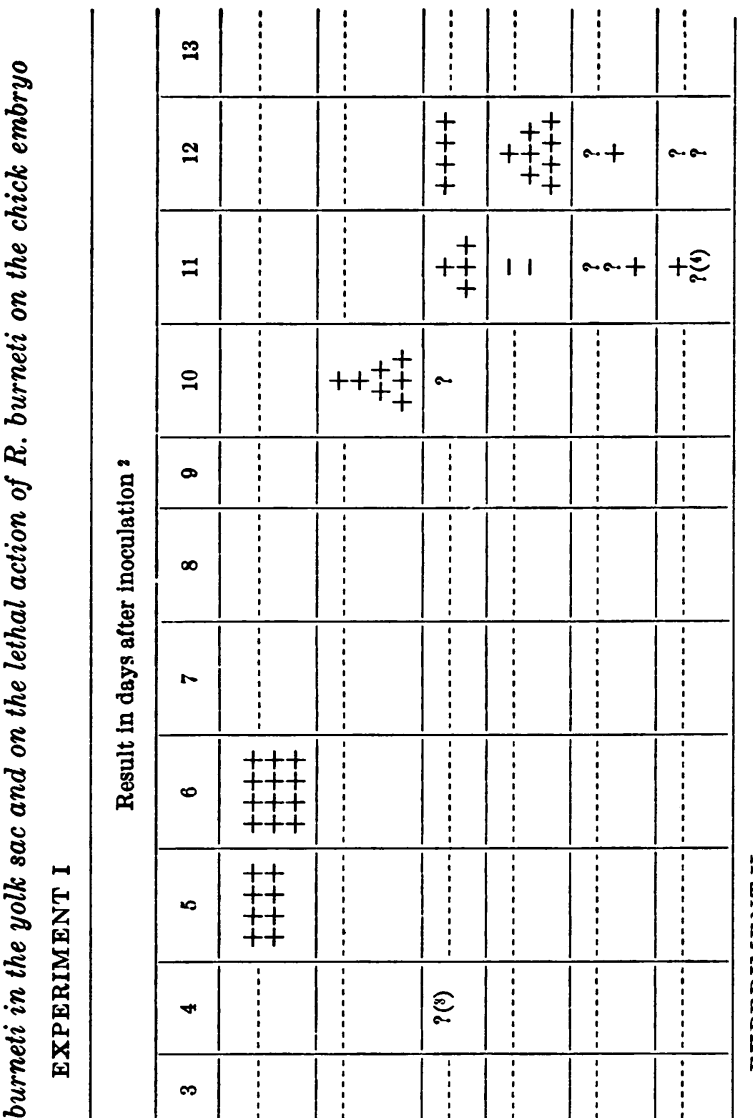

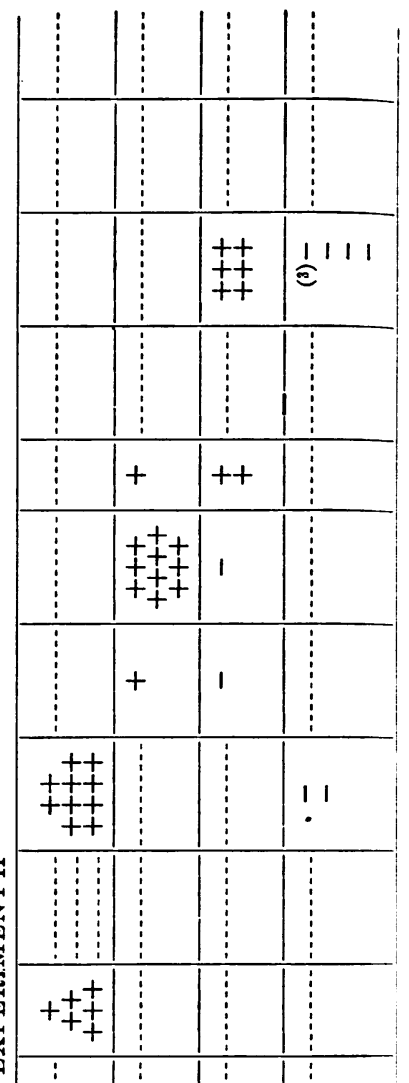

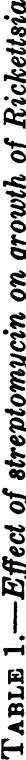

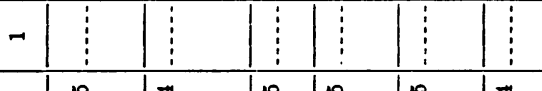

\begin{tabular}{|c|c|c|c|c|c|c|}
\hline 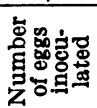 & 0 & $\sigma$ & $\infty$ & مـ & 10 & $\sigma$ \\
\hline 8 & : & $\overline{5}$ & $\overline{5}$ & 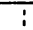 & 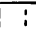 & $!$ \\
\hline
\end{tabular}




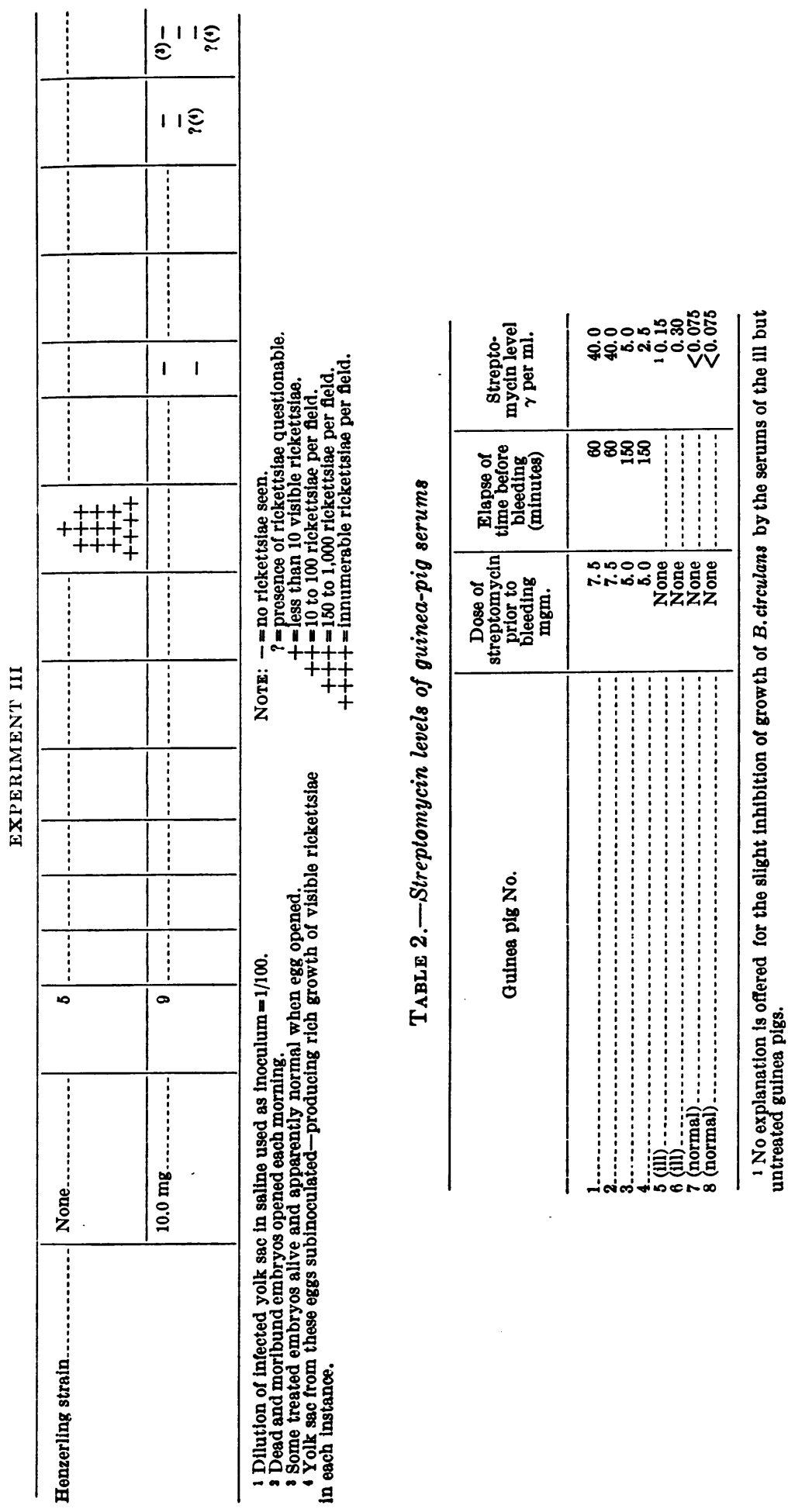


prolonged. Larger doses of streptomycin appeared to produce higher degrees of rickettsiostatic action than smaller doses. The action of streptomycin even in the largest dose $(10 \mathrm{mg} / \mathrm{egg})$ was manifestly not rickettsiocidal since treated yolk sacs, apparently free of visible rickettsiae, on subculture in embryonated eggs yielded a uniformly heavy growth of rickettsiae.

Effect of streptomycin in experimental infection in guinea pigs.-The following experiments were designed to determine the effect of treatment with streptomycin on the lethal action of $R$. burneti in guinea pigs.

Highly lethal yolk sac suspensions of the Dyer strain of $R$. burneti were used to infect the guinea pigs. Preliminary titrations of the infecting suspensions inoculated intraperitoneally indicated that a 1-100 (or 1-1,000) dilution would produce death of all inoculated guinea pigs in 6 to 8 days. A 1-10,000 dilution was found to be only slightly less virulent. A stock suspension diluted at 1-10 in skim milk was preserved at $-50^{\circ} \mathrm{C}$. and was used in each experiment. Both the 1-100 and 1-10,000 dilutions produced high fever $\left(40.5^{\circ} \mathrm{C}\right.$. to $41.5^{\circ}$ C.), inactivity, and anorexia within 24 to 48 hours. Most of the untreated guinea pigs which died within 8 days after inoculation with the infectious suspension were found on autopsy to have ruptured spleens. In order to counteract such overwhelming doses of $R$. burneti, treatment with streptomycin was begun 3-4 hours after injecting the infecting suspensions. The total daily dosage of streptomycin for each guinea pig in each of the experiments was $30 \mathrm{mgm}$. contained in 6 cc. of saline. Three to six inoculations were made daily, 8 to 4 hours apart, respectively. Based upon the weight of the guinea pigs (600-700 gm.), the dosage varied approximately from 40 to 50 $\mathrm{mgm} / \mathrm{kg}$. of body weight. The streptomycin was given subcutaneously.

Four treated guinea pigs in experiment IV (table 3) were bled during treatment and their serums tested for streptomycin content. The concentration of streptomycin in guinea pig serum was determined by a standard method (9). In this method dilutions of serum which inhibited the growth of Bacillus circulans in broth were compared with similar dilutions of a standardized streptomycin solution. The results were expressed in terms of micrograms of the purified streptomycin (table 2).

Table 3 gives the results of two guinea-pig experiments in which the effect of streptomycin on the lethal action of $R$. burneti is shown. Despite the small numbers of animals used, the differences between the control groups (1 survivor of 28 inoculated) and the streptomycintreated groups (19 survivors of 24 inoculated) could not have been expected to occur by chance. 


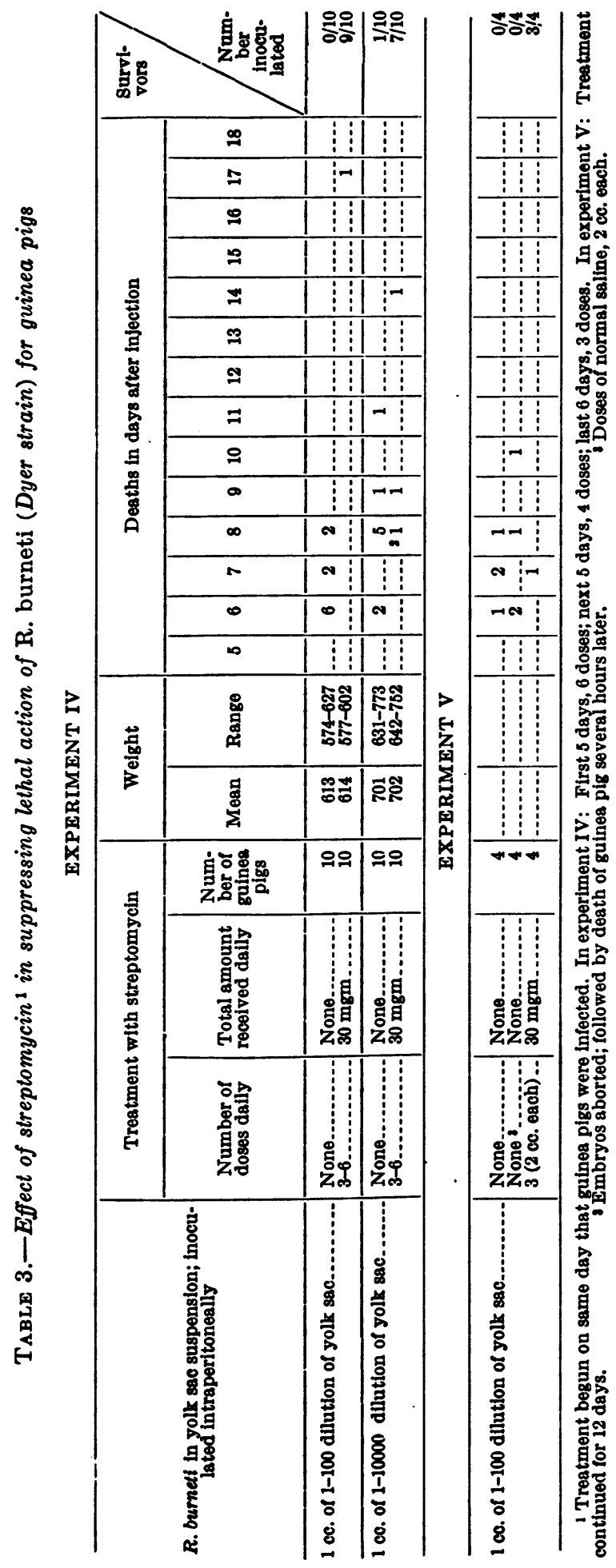


The effect of treatment with streptomycin on the febrile manifestations of $Q$ fever was less clearly shown. Treated guinea pigs had only a slightly longer incubation period (average 2.2 days) before onset of fever than the controls (average 1.4). In general the treated pigs carried a fever as long as the controls-however, the control pigs died early, many of them showing a subnormal temperature on the day of death.

\section{SUMMARY}

Crystalline streptomycin, in doses as low as 0.5 miligram, was found to exercise a rickettsiostatic action on the growth of $R$. burneti in the yolk sacs of fertile eggs. Although there was no evidence of rickettsiocidal action with doses as high as $10 \mathrm{mg}$. per egg, inhibition of growth was greater with the higher doses. Guinea pigs inoculated with highly virulent yolk sac suspensions of $R$. burneti showed a low mortality rate when treated with $30 \mathrm{mg}$. of streptomycin given three to six times daily by the subcutaneous route.

The amounts of streptomycin per kilogram of body weight which were used in the guinea pig experiments were comparable to dosages recommended for treatment of streptomycin-susceptible diseases in man. Treatment of the guinea pigs was initiated at a much earlier stage than could be achieved in human infection with $Q$ fever. However, the infectious doses administered to the guinea pigs were overwhelmingly large and the primary objective of the experiments was to observe the action of streptomycin in preventing death of guinea pigs infected with $Q$ fever.

\section{REFERENCES}

(1) Topping, Norman H., Shepard, Charles C., and Irons, J. V.: $Q$ fever in the United States. J. A. M. A. 133: 813 (March 1947).

(2) Shepard, Charles C.: An outbreak of $Q$ fever in a Chicago packing house. Am. J. Hyg. 46: 185 (Sept. 1947).

(3) Gsell, O.: Pneumonies a Rickettsia burneti. Med. et Hyg. 108: 317 (Oct. 1947).

(4) Robbins, F. C. and Ragan, C. A.: $\mathbf{Q}$ fever in the Mediterranean area: Report of its occurrence in Allied troops. . Am. J. Hyg. 44: 6 (July 1946).

(5) Commission on Acute Respiratory Diseases. Identification and characteristics of the Balkan grippe strain of Rickettsia burneti. Am. J. Hyg. 44: 110 (July 1946).

(6) Cheney, G. and Geib, W. A.: The identification of $Q$ fever in Panama. Am. J. Hyg. 44: 158 (July 1946).

(7) Smadel, Joseph F.; Jackson, Elizabeth G.; and Gould, Ross L.: Factors influencing the growth of rickettsiae I. Rickettsiostatic effect of streptomycin in experimental infections. J. Immunol. 57: 273 (Nov. 1947).

(8) Morgan, H. R.; Stevens, D. A.; and Snyder, J. C.: Effect of streptomycin on growth of rickettsiae in eggs. Proc. Soc. Exper. Biol. \& Med. 64: 342 (March 1947).

(9) Price, C. W.; Nielsen, P. K.; and Welch, H.: The estimation of streptomycin in body fluids. Science. 103: 56 (Jan. 1946). 


\title{
STUDIES OF THE ACUTE DIARRHEAL DISEASES
}

\author{
XVIII. Epidemiology 12
}

By Albert V. Hardy, ${ }^{3}$ and James Watt, Surgeon, United States Public Health Service

In preceding papers the general plan of study was stated, the bacteriological findings given, and the clinical data described. The accumulated epidemiological observations are presented here. These data are largely a record of the findings in a total of 825 households in New Mexico, Georgia, and New York. Supplementary observations on institutional inmates and military personnel are included.

\section{STUDY AREAS}

Four study areas were selected to represent those with very high, high, medium, and low reported mortality from the diarrheal diseases.

TABLE 1.-Reported mortality from the diarrheal diseases in the United States and in the four areas in which studies were conducted 1

\begin{tabular}{|c|c|c|c|c|c|c|c|c|c|c|c|c|c|c|c|}
\hline \multirow[b]{3}{*}{ Year } & \multicolumn{15}{|c|}{ Mortality per 100,000 population per annum } \\
\hline & \multicolumn{3}{|c|}{ United States } & \multicolumn{3}{|c|}{ Puerto Rico } & \multicolumn{3}{|c|}{ New Mexico } & \multicolumn{3}{|c|}{ Georgia } & \multicolumn{3}{|c|}{$\underset{\text { State }}{\text { New York }}$} \\
\hline & 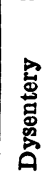 & 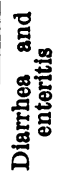 & 恶 & 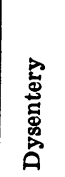 & 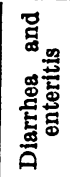 & 吾 & 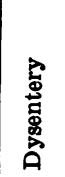 & 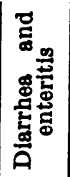 & 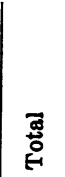 & 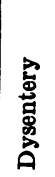 & 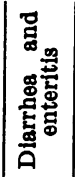 & 恶 & 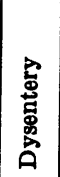 & 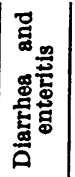 & 覀 \\
\hline $\begin{array}{l}1941 \\
1940 \\
1939 \\
1938 \\
1937 \\
1936\end{array}$ & $\begin{array}{l}1.8 \\
1.9 \\
1.9 \\
2.3 \\
2.3 \\
2.4 \\
1.9\end{array}$ & \begin{tabular}{|l}
10.5 \\
10.3 \\
11.6 \\
14.3 \\
14.7 \\
16.4 \\
14.1
\end{tabular} & $\begin{array}{l}12.3 \\
12.2 \\
13.5 \\
16.6 \\
17.0 \\
18.8 \\
16.0\end{array}$ & $\begin{array}{r}11.5 \\
5.2 \\
6.8 \\
11.2 \\
13.5 \\
10.7 \\
6.7\end{array}$ & $\begin{array}{l}417.1 \\
405.1 \\
396.0 \\
314.4 \\
473.6 \\
469.1 \\
359.5\end{array}$ & \begin{tabular}{|l|}
428.6 \\
410.3 \\
402.8 \\
425.6 \\
487.1 \\
479.8 \\
366.2 \\
\end{tabular} & $\begin{array}{r}19.7 \\
14.1 \\
11.3 \\
14.2 \\
11.1 \\
14.7 \\
5.7\end{array}$ & $\begin{array}{l}50.4 \\
45.3 \\
44.7 \\
49.8 \\
81.2 \\
71.2 \\
77.7\end{array}$ & $\begin{array}{l}70.1 \\
59.4 \\
56.0 \\
64.0 \\
92.3 \\
85.9 \\
83.4\end{array}$ & $\begin{array}{l}3.4 \\
3.9 \\
4.3 \\
6.4 \\
4.2 \\
5.1 \\
5.3\end{array}$ & \begin{tabular}{|l|}
17.7 \\
17.3 \\
17.6 \\
27.5 \\
20.6 \\
24.7 \\
22.8
\end{tabular} & \begin{tabular}{|l|}
21.1 \\
21.2 \\
21.9 \\
33.9 \\
24.8 \\
29.8 \\
28.1
\end{tabular} & $\begin{array}{r}0.5 \\
.2 \\
.3 \\
.4 \\
.4 \\
.4 \\
.4\end{array}$ & $\begin{array}{l}4.2 \\
4.3 \\
5.7 \\
6.1 \\
7.1 \\
7.1 \\
7.5\end{array}$ & \begin{tabular}{|l|}
4.7 \\
4.5 \\
6.0 \\
6.5 \\
7.5 \\
7.5 \\
7.9
\end{tabular} \\
\hline
\end{tabular}

1 Data from Vital Statistics, Special Reports (State Summaries). U. S. Bureau of the Census.

There is a wide variation in mortality rates in the United States as a whole and in the States and Territory in which the study areas were situated (table 1). The reported mortality from dysentery, diarrhea and enteritis in Puerto Rico was much higher than in any other Territory or State. The high rates for New Mexico were similar to the rates for Arizona. Georgia was selected as representative of the Southern States with from 10 to 50 reported deaths from diarrheal diseases per 100,000 population per annum. Elsewhere in the United

1 From the Division of Infectious Diseases, National Institute of Health, with the cooperation of State, insular, and local health departments of the areas in which the studies were conducted, the Indian Medical Service, and the DeLamar Institute of Public Health, Columbia University.

2 See end of article for other papers in this series.

3 From the Bureau of Laboratories, Florida State Board of Healtb. 
States the mortality from these causes was in line with that in New York State, the Pacific States having the most favorable record.

Investigations were begun in New Mexico in 1936 and were continued there through 1938. The area selected for study was centrally located Bernalillo County and surrounding Indian communities. The population of the county was 45,430 in 1930 and 69,391 in 1940 , an increase of 52.7 percent. The city of Albuquerque and its suburbs included more than half the residents. The remainder lived on irrigated farms in the river valley, in villages scattered in the hills, and in widely separated ranch homes. Racial groups were not separately enumerated in the Federal census, but the State Department of Education found that the pupils in the elementary schools in Bernalillo County were divided about equally between Englishspeaking and Spanish-speaking families.

Dougherty County, Georgia, selected as a representative southern county, was studied during 1939 and 1940. It is in the southwestern section of the State, with a population in 1940 of 28,565. More than half were residents of the city of Albany. The remainder lived on farms or in the few small villages. More than half (54 percent) were Negroes.

The observations in New York were obtained in Manhattan, New York City, during 1939 and 1940. The rarity of the diarrheal diseases made it practicable to obtain observations from this population group which numbered 1,889,924 in 1940 and included 15.8 percent Negroes.

The epidemiological data from Puerto Rico, studied during 1941 and 1942, were not adequate for statistical analysis and will be used for general comparative purposes only. The study area included a small town and a rural municipality.

The inmates of 10 institutions for the mentally defective or the mentally ill (8 in New York, 1 in Illinois, and 1 in Puerto Rico) were studied. Some observations were obtained, also, from military units in Puerto Rico.

\section{INCIDENCE}

Mortality data provide at most a crude measure of the relative incidence of diarrheal diseases. The wide variations by locality are evident in table 1. The importance of Shigellae as a cause of death from diarrheal disease is suggested in table 2. Of the 51 deaths among New Mexico and Georgia cases under 2 years of age, 39 individuals or 75 percent, had stool cultures positive for Shigellae. There was only 1 death among patients over 2 years of age.

The age distribution of cases reported by physicians or discovered through epidemiological inquiries and the annual morbidity rates per 
TABLE 2.-Shigella infection in patients dying of diarrheal diseases in study areas in New Mexico (1937-38) and Georgia (1939-1940) by age groups

\begin{tabular}{|c|c|c|c|c|c|}
\hline \multirow{2}{*}{ Age in months } & \multirow{2}{*}{$\begin{array}{l}\text { Number } \\
\text { of deaths } \\
\text { in series }\end{array}$} & \multicolumn{2}{|c|}{$\begin{array}{l}\text { Culture-positive } \\
\text { for Shigellae }\end{array}$} & \multicolumn{2}{|c|}{$\begin{array}{l}\text { Culture-negative } \\
\text { for Shigellae }\end{array}$} \\
\hline & & Number & Percent & Number & Percent \\
\hline $\begin{array}{l}0-5 \\
6-11 \\
24 \text { and over }\end{array}$ & $\begin{array}{r}17 \\
21 \\
13 \\
1\end{array}$ & $\begin{array}{r}9 \\
19 \\
11 \\
0\end{array}$ & $\begin{array}{l}52.9 \\
90.1 \\
84.6\end{array}$ & $\begin{array}{l}\mathbf{8} \\
\mathbf{2} \\
\mathbf{2} \\
1\end{array}$ & $\begin{array}{r}47.1 \\
9.9 \\
15.4 \\
0 . .\end{array}$ \\
\hline Total..- & 52 & 39 & 75.0 & 13 & 25.0 \\
\hline
\end{tabular}

1,000 population are given in table 3. Reported or discovered diarrheal disease known to be due to Shigellae varied from 3.6 per 1,000

TABLE 3.-Annual morbidity rates for acute diarrheal diseases in New Mexico, Georgia, and New York based on cases reported by physicians and found by epidemiological investigation

\begin{tabular}{|c|c|c|c|c|c|c|c|c|c|c|c|c|c|c|c|c|}
\hline \multirow{4}{*}{ Age in years } & \multicolumn{8}{|c|}{ Number of cases } & \multicolumn{8}{|c|}{ Cases per 1,000 population per annum } \\
\hline & \multicolumn{4}{|c|}{ Positive 1} & \multicolumn{4}{|c|}{ Negative 8} & \multicolumn{4}{|c|}{ Positive 1} & \multicolumn{4}{|c|}{ Negative ${ }^{2}$} \\
\hline & \multicolumn{2}{|c|}{$\underset{\text { ico }}{\text { Mew Mex }}$} & \multirow{2}{*}{$\mid \begin{array}{l}\infty \\
\infty \\
0 \\
0 \\
0 \\
\vdots \\
\vdots \\
0 \\
0 \\
0\end{array}$} & \multirow{2}{*}{ 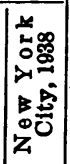 } & \multicolumn{2}{|c|}{${ }_{i c 0}^{\text {New Mex- }}$} & \multirow{2}{*}{$\mid \begin{array}{l}\infty \\
\infty \\
\infty \\
\infty \\
\infty \\
0 \\
0 \\
0 \\
0 \\
0 \\
0\end{array}$} & \multirow{2}{*}{ 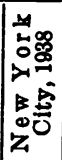 } & \multicolumn{2}{|c|}{$\underbrace{\text { New Mex }}_{\text {ico }}$} & \multirow{2}{*}{$\mid \begin{array}{l}\infty \\
\infty \\
0 \\
0 \\
0 \\
0 \\
0 \\
0 \\
0 \\
0 \\
0\end{array}$} & \multirow{2}{*}{ 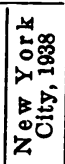 } & \multicolumn{2}{|c|}{$\underset{\text { ico }}{\text { New Mex- }}$} & \multirow{2}{*}{$\mid \begin{array}{l}\infty \\
\infty \\
\infty \\
\infty \\
\infty \\
\infty \\
0 \\
0 \\
0 \\
0 \\
0\end{array}$} & \multirow{2}{*}{ 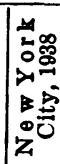 } \\
\hline & 馬 & 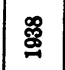 & & & $\underset{\mathscr{\varpi}}{\mathscr{్}}$ & $\underset{\mathbb{\sim}}{\infty}$ & & & ळ్త & 怘 & & & 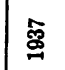 & 怘 & & \\
\hline $\begin{array}{l}4 \\
50-14 \\
15-19 \\
20-24 \\
25-34 \\
35-44 \\
45-54 \\
55-64 \\
65 \text { and over } \\
\text { Unknown }\end{array}$ & $\begin{array}{r}35 \\
25 \\
15 \\
6 \\
3 \\
7 \\
5 \\
4 \\
7 \\
11 \\
0 \\
5 \\
1 \\
2 \\
0\end{array}$ & $\begin{array}{r}52 \\
40 \\
34 \\
17 \\
11 \\
13 \\
9 \\
7 \\
10 \\
24 \\
7 \\
5 \\
5 \\
2 \\
1\end{array}$ & $\begin{array}{c}10 \\
27 \\
7 \\
4 \\
2 \\
5 \\
0 \\
5 \\
4 \\
3 \\
5 \\
1 \\
0 \\
2 \\
0\end{array}$ & $\begin{array}{r}7 \\
9 \\
12 \\
8 \\
10 \\
22 \\
3 \\
0 \\
3 \\
2 \\
1 \\
0 \\
1 \\
1 \\
3\end{array}$ & $\begin{array}{r}31 \\
16 \\
9 \\
2 \\
3 \\
6 \\
8 \\
3 \\
6 \\
9 \\
6 \\
4 \\
1 \\
1 \\
1\end{array}$ & $\begin{array}{r}92 \\
52 \\
22 \\
10 \\
7 \\
17 \\
7 \\
7 \\
17 \\
22 \\
25 \\
14 \\
3 \\
5 \\
8\end{array}$ & $\begin{array}{r}27 \\
13 \\
11 \\
4 \\
5 \\
4 \\
9 \\
7 \\
7 \\
15 \\
15 \\
4 \\
0 \\
2 \\
1\end{array}$ & $\begin{array}{r}134 \\
32 \\
13 \\
8 \\
4 \\
16 \\
10 \\
1 \\
0 \\
1 \\
1 \\
0 \\
1 \\
0 \\
4\end{array}$ & $\begin{array}{r}21.0 \\
16.3 \\
9.5 \\
3.7 \\
1.9 \\
.9 \\
.7 \\
.6 \\
1.2 \\
1.2 \\
0 \\
1.0 \\
.3 \\
.8\end{array}$ & \begin{tabular}{|r|}
30.1 \\
25.0 \\
20.8 \\
10.2 \\
6.6 \\
1.5 \\
1.3 \\
1.1 \\
1.7 \\
2.6 \\
.9 \\
.9 \\
1.4 \\
.8 \\
-
\end{tabular} & $\begin{array}{r}11.4 \\
30.7 \\
7.3 \\
4.1 \\
2.1 \\
.9 \\
0.9 \\
1.0 \\
.9 \\
.5 \\
1.0 \\
.3 \\
1.2 \\
1.2\end{array}$ & $\begin{array}{c}0.3 \\
.4 \\
.5 \\
.3 \\
.4 \\
.42 \\
(4) \\
0 \\
(4) \\
(4) \\
(4) \\
0 \\
(4) \\
(4) \\
(4)\end{array}$ & $\begin{array}{r}18.6 \\
10.4 \\
5.7 \\
1.2 \\
1.9 \\
1.7 \\
.5 \\
.1 .1 \\
1.0 \\
.8 \\
.8 \\
.3 \\
.4 \\
-. .-\end{array}$ & $\begin{array}{r}53.2 \\
32.5 \\
13.5 \\
6.0 \\
4.2 \\
2.0 \\
1.0 \\
1.1 \\
2.9 \\
2.4 \\
3.2 \\
2.6 \\
.9 \\
1.9 \\
- \\
-. . .\end{array}$ & \begin{tabular}{|r|}
31.0 \\
14.9 \\
11.9 \\
4.1 \\
5.2 \\
.7 \\
1.8 \\
1.4 \\
1.7 \\
2.5 \\
3.0 \\
1.1 \\
0 \\
1.2
\end{tabular} & \begin{tabular}{l}
6.4 \\
1.5 \\
.5 \\
.3 \\
.2 \\
.1 \\
.1 \\
$(4)$ \\
0 \\
$(4)$ \\
$(4)$ \\
0 \\
$(4)$ \\
0 \\
\hdashline-
\end{tabular} \\
\hline Total & 126 & 237 & 75 & 82 & 106 & 308 & $\overline{124}$ & 227 & $\overline{2.0}$ & $\overline{3.6}$ & $\overline{1.7}$ & $\overline{.04}$ & $\overline{1.7}$ & 4.7 & 2.9 & .13 \\
\hline
\end{tabular}

1 Shigellae isolated by fecal culture.

2 Shigellae not isolated by fecal culture.

2 Cases observed in 18 months.

4 Less than 0.05 .

population per annum in New Mexico in 1938 to 0.04 in New York City. The culture-negative cases varied similarly in incidence. These figures for shigellosis are conservative estimates since all examinations could not be made under optimum conditions. For example, if all cases had been examined with multiple cultures during the acute phase of the illness, a part, at least, of the negative group would have had positive cultures.

The following factors must be considered in the further evaluation of these data: (1) The discovered rates were higher in New Mexico in 1938 than in 1937, the 2 years our study was in progress. We 
believe this reflects only a more complete reporting of cases in 1938 since during the second year the number of reported deaths from diarrheal diseases dropped substantially in the county and State, and the practicing physicians recognized a distinct decline in morbidity; (2) The completeness of reporting in Georgia probably compares favorably with that in New Mexico in 1938, since the study area was smaller and the laboratory was open throughout the year thus permitting a more intensive study; (3) In both of these States (New Mexico, and Georgia), it was apparent that the reporting was incomplete especially during the months of high incidence, since additional individuals who were or had been ill recently with acute diarrhea were readily discovered by case-finding procedures; (4) In New York City, by contrast, cases were hard to find; physicians in practice and those attending child hygiene clinics commonly commented that endemic acute diarrhea was rarely encountered. The higher proportion of mild cases reported in New York suggests reasonably complete recording. Incomplete reporting usually reveals a preponderance of severe illnesses.

Indians were excluded from table 3 since satisfactory population data were not available. Most of the cases among Indians were reported from hospitals which served reservations in New Mexico and Arizona. During the 2 years, 93 positive and 78 negative cases were observed. While comparative rates for Indians cannot be presented, it was apparent that the incidence of infectious diarrheal disease in this population group was high.

A satisfactory measure of morbidity from diarrheal diseases could not be obtained in Puerto Rico since the usual case-reporting procedures were not sufficiently developed. Post-mortem fecal cultures obtained by rectal swabs from infants reported to have died of diarrhea did reveal an annual mortality of approximately one death from Shigella infection per 1,000 population per annum. This is approximately 10 times the mortality rate from all diarrheal diseases on the continent. A comparable difference in morbidity rates would be expected.

The bacteriological results of culture surveys of general population groups were reported in XIII of this series. The individuals were questioned about current and preceding (within 3 months) attacks of diarrhea. The number of cases found and the annual morbidity rates for the selected population groups are shown in table 4 . A very high morbidity from diarrheal disorders is shown. Comparison of these rates with those given in table 3 emphasizes the fact that only a small portion of the cases of shigellosis and other diarrheal disorders are seen by physicians. In general, we believe that the high rates approximate the true morbidity from these diseases, while the reported cases are a partial measure of the more severe illnesses of 
this nature. Some confirmation of this belief was obtained in our studies of institutional groups. For each case which normally would be considered as bacillary dysentery by the local authorities, a careful study would reveal a number of individuals with proved infection whose only symptoms were mild diarrhea or slight fever.

TABLE 4.-Annual morbidity rates of acute diarrheal diseases in New Mexico and Georgia based on cases found by intensive follow-up studies of selected general population groups ${ }^{1}$

\begin{tabular}{|c|c|c|c|c|c|c|c|c|c|c|c|c|c|c|c|}
\hline \multirow[b]{3}{*}{ Age in years } & \multirow{2}{*}{\multicolumn{3}{|c|}{$\begin{array}{l}\text { Person-years } \\
\text { observation }\end{array}$}} & \multicolumn{6}{|c|}{ Cases discovered } & \multicolumn{6}{|c|}{ Cases per 1,000 person-years } \\
\hline & & & & \multicolumn{3}{|c|}{$\begin{array}{c}\text { Culture-posi- } \\
\text { tive }\end{array}$} & \multicolumn{3}{|c|}{$\begin{array}{c}\text { Culture-nega- } \\
\text { tive }\end{array}$} & \multicolumn{3}{|c|}{$\underset{\text { tive }}{\text { Culture-posi- }}$} & \multicolumn{3}{|c|}{$\begin{array}{c}\text { Culture-nega- } \\
\text { tive }\end{array}$} \\
\hline & 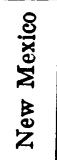 & 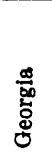 & जే & 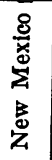 & $\begin{array}{l}\text { 吕 } \\
\text { 형 } \\
0\end{array}$ & 蹗 & 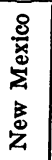 & 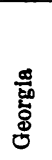 & 要 & 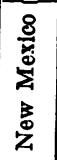 & 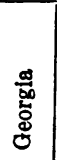 & 惡 & 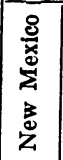 & 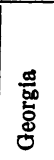 & 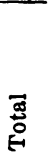 \\
\hline $\begin{array}{l}\text { Under } 1 \\
12 \\
34 \\
45-9 \\
10-14 \\
20-24 \\
25-34 \\
45 \text { and over }\end{array}$ & $\begin{array}{r}66 \\
14 \\
23 \\
23 \\
24 \\
102 \\
56 \\
31 \\
39 \\
70 \\
40 \\
39 \\
\end{array}$ & $\begin{array}{r}32 \\
28 \\
28 \\
32 \\
21 \\
152 \\
107 \\
57 \\
66 \\
125 \\
110 \\
158 \\
\end{array}$ & $\begin{array}{r}98 \\
42 \\
51 \\
55 \\
45 \\
254 \\
163 \\
88 \\
105 \\
195 \\
150 \\
197\end{array}$ & $\begin{array}{r}13 \\
8 \\
7 \\
7 \\
2 \\
17 \\
7 \\
2 \\
7 \\
3 \\
4 \\
7\end{array}$ & $\begin{array}{l}3 \\
4 \\
2 \\
1 \\
0 \\
1 \\
3 \\
1 \\
5 \\
5 \\
4 \\
4\end{array}$ & \begin{tabular}{r|r}
16 \\
12 \\
9 \\
8 \\
2 \\
2 \\
18 \\
10 \\
3 \\
12 \\
8 \\
8 \\
8 \\
11
\end{tabular} & $\begin{array}{r}20 \\
8 \\
6 \\
7 \\
3 \\
14 \\
5 \\
6 \\
2 \\
5 \\
7 \\
4\end{array}$ & \begin{tabular}{r|}
24 \\
21 \\
15 \\
10 \\
6 \\
14 \\
16 \\
4 \\
12 \\
12 \\
30 \\
24 \\
34 \\
\end{tabular} & $\begin{array}{l}44 \\
29 \\
21 \\
17 \\
9 \\
28 \\
21 \\
10 \\
14 \\
35 \\
31 \\
38\end{array}$ & \begin{tabular}{|c|}
197 \\
571 \\
304 \\
304 \\
83 \\
167 \\
125 \\
65 \\
179 \\
43 \\
100 \\
179 \\
\end{tabular} & $\begin{array}{r}94 \\
143 \\
71 \\
31 \\
0 \\
7 \\
28 \\
18 \\
76 \\
40 \\
36 \\
25\end{array}$ & $\begin{array}{r}163 \\
286 \\
176 \\
145 \\
44 \\
71 \\
61 \\
34 \\
114 \\
41 \\
53 \\
56\end{array}$ & \begin{tabular}{|r|}
303 \\
571 \\
261 \\
304 \\
125 \\
137 \\
89 \\
193 \\
51 \\
71 \\
175 \\
103 \\
\end{tabular} & $\begin{array}{r}750 \\
750 \\
536 \\
313 \\
250 \\
92 \\
150 \\
70 \\
182 \\
240 \\
218 \\
215\end{array}$ & $\begin{array}{l}449 \\
690 \\
412 \\
309 \\
200 \\
110 \\
129 \\
114 \\
133 \\
179 \\
207 \\
193\end{array}$ \\
\hline Total & 527 & 916 & 1,443 & 84 & 33 & 117 & 87 & 210 & 297 & 159 & 36 & 81 & 165 & 229 & 206 \\
\hline
\end{tabular}

1 History of diarrheal disease obtained at time of culture and all positive households revisited for additional questioning. In New Mexico new families were seen each month, in Georgis the same families were revisited on a monthly basis.

An exact measure of the ratio of shigellosis to nonspecific diarrheas was not obtained since general population surveys were made without regard to previous history of illness. The following facts indicate that the ratio shown is a minimal figure. Fifty-three of the individuals cultured were ill on the day they were examined. A Shigella type was isolated from 34 (64 percent) of these individuals. In contrast, 361 well persons with a history of diarrhea within 3 months were cultured. Only 83 (23 percent) of these patients had a positive culture. It is obvious that more frequent cultures would have increased the number of illnesses found to be associated with specific infection with a member of the Shigella group.

The prevalence of subclinical (asymptomatic) infections was also determined by these survey cultures and is discussed in detail in XIII of this series. The rates varied widely by region. The discovered prevalence of 4 percent for the New Mexico and Georgia areas indicates a very high annual incidence of infection since the average duration of an untreated Shigella infection is approximately 6 weeks. By contrast, in New York City carriers of Shigella were 
rarely identified. Of 1,659 individuals tested in 1939 and 1940, only two carriers were found. More recently, all persons admitted to a mental hospital serving this urban population were examined culturally. No carrier of Shigella was found in 2,497 individuals tested during a period of 20 months. In an urban area of this character, the annual incidence rate of shigellosis must be quite low.

Extensive surveys of institutional population groups were conducted also. Here too, the prevalence of Shigella infection varied widely. When clinical infections were occurring at the rate of 2 or more per week, the total prevalence usually was from 5 to 30 percent in the particular group. The rate was usually below 5 percent when clinical cases were less frequent as well as in the period shortly after the apparent termination of an outbreak. In five groups, during the 3 to 6 months after an outbreak about 1 percent were found infected. In a few of these groups repeated examinations over a year or more failed to reveal any pathogenic Shigella.

There was a similar wide range in the number of subclinical infections found in military units in Puerto Rico. With a large number of clinical cases, the rates of Shigella infection were high; with few or no clinical cases, the rates were low.

\section{AGE DISTRIBUTION OF DEATHS AND CASES}

There were significant variations in the age distribution of proved cases of shigellosis and other diarrheal disorders as observed in the main study areas (tables $2,3,4$, and 5).

TABLE 5.-The prevalence of passive carriers of shigellae in New Mexico and Georgia as determined by fecal cultures on healthy individuals in the general population 1

\begin{tabular}{|c|c|c|c|c|c|c|c|c|c|}
\hline \multirow{2}{*}{ Age } & \multicolumn{3}{|c|}{ Number of fecal cultures } & \multicolumn{3}{|c|}{$\underset{\text { Nhigellac }}{\text { Number positive for }}$} & \multicolumn{3}{|c|}{$\begin{array}{c}\text { Percent positive for } \\
\text { shigellac }\end{array}$} \\
\hline & $\underset{\text { Mexico }}{\text { New }}$ & Georgia & Total & $\underset{\text { Mexico }}{\text { New }}$ & Georgia & Total & $\begin{array}{c}\text { New } \\
\text { Mexico }\end{array}$ & Georgia & Total \\
\hline 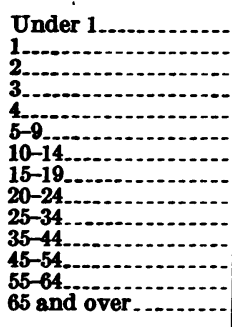 & $\begin{array}{r}214 \\
37 \\
72 \\
73 \\
85 \\
370 \\
207 \\
111 \\
145 \\
265 \\
146 \\
67 \\
37 \\
36 \\
\end{array}$ & $\begin{array}{r}94 \\
82 \\
93 \\
112 \\
74 \\
586 \\
407 \\
222 \\
240 \\
447 \\
406 \\
333 \\
115 \\
130 \\
\end{array}$ & $\begin{array}{l}308 \\
119 \\
165 \\
185 \\
159 \\
956 \\
614 \\
333 \\
385 \\
712 \\
552 \\
400 \\
152 \\
166 \\
\end{array}$ & $\begin{array}{r}1 \\
2 \\
2 \\
3 \\
10 \\
6 \\
40 \\
15 \\
7 \\
17 \\
17 \\
12 \\
5 \\
1 \\
11\end{array}$ & $\begin{array}{r}1 \\
4 \\
3 \\
1 \\
5 \\
2 \\
22 \\
7 \\
4 \\
4 \\
5 \\
1 \\
6 \\
5 \\
0 \\
2 \\
\end{array}$ & $\begin{array}{r}2 \\
6 \\
6 \\
11 \\
11 \\
62 \\
22 \\
11 \\
22 \\
18 \\
18 \\
10 \\
1 \\
6\end{array}$ & $\begin{array}{r}0.5 \\
5.4 \\
4.2 \\
13.7 \\
7.1 \\
10.8 \\
7.3 \\
6.3 \\
11.7 \\
6.4 \\
8.2 \\
7.5 \\
2.7 \\
11.1\end{array}$ & $\begin{array}{l}1.0 \\
4.9 \\
3.2 \\
.9 \\
6.8 \\
3.9 \\
1.7 \\
1.8 \\
2.1 \\
.2 \\
1.5 \\
1.5 \\
1.5\end{array}$ & $\begin{array}{l}0.7 \\
5.0 \\
3.5 \\
5.9 \\
6.9 \\
6.5 \\
3.6 \\
3.3 \\
5.7 \\
2.5 \\
3.3 \\
2.5 \\
.7 \\
3.6\end{array}$ \\
\hline Total & 1,865 & 3,341 & 5,206 & 140 & 66 & 206 & 7.5 & 2.0 & 4.0 \\
\hline
\end{tabular}

1 All individuals stated that they had had no diarrheal disorder for at least 1 year before the examination.

Deaths from all diarrheal disorders were concentrated in the first years of life. During the studies of general population groups, 39 
deaths from shigellosis were observed (table 2); there were also 13 diarrheal-disease deaths involving individuals whose stool cultures were negative. The majority of the deaths apparently due to shigellosis occurred in the infants 6 to 18 months old. By contrast, 8 of the 13 deaths in the negative group were infants less than 6 months old.

The nonfatal but relatively severe diarrheal diseases revealed by case reporting were also most common in young children (table 3 ). The highest rate of proved shigellosis in reported cases in New Mexico was in infants under 1 year; in Georgia the rate was highest in children 1 to 2 years old. The rates then declined progressively up to 4 years of age. The morbidity rates by age for New York City children were low and did not show significant age variation. The age distribution of the disorders that were culture-negative differed chiefly in the relatively higher incidence in infants under 1 year.

The case rates by age for the disorders are revealed (table 4) by surveys of the general population. A much larger proportion of these cases were milder than those reported by physicians (table 3 ). This type of case finding revealed a much higher attack rate in all age groups for both culture-positive and culture-negative cases. Young children continued to show the highest rates.

The notable features of the age distribution of the subclinical infections (table 5) are the very low rates for infants, the uniform and high rates at ages 1 to 9 years, and the slight decline in the rates for older children and adults.

Two observations on institutional inmates were particularly impressive: (1) Dysentery was a recurrent problem in groups of young children; (2) the clinical attack rate was strikingly high in patients newly admitted to any group in which the infection was persistent endemically.

Thus, when infants under 1 year were infected with Shigellae, almost all had clinical symptoms; the cases tended to be severe, and before specific chemotherapy was available many terminated fatally. The total prevalence was the highest in the second year of life, but here fatal infections were less frequent, and clinically mild disorders and subclinical infections were more common. With increasing age there was a decline in the severity of the disease and an increase in the relative proportion of subclinical infections. The latter, however, remained at a high and relatively constant level from ages 1 through 9 years. Shigellosis in persons above this age was usually a subclinical infection. The discovered clinical cases tended to be mild; severe bacillary dysentery, as commonly described, was rarely encountered. In New Mexico, where Shigella infections were prevalent, the largest number of reported cases with a positive culture were in infants under 
1 year. In Georgia, where the infection was less frequent, the peak of reported cases was in the second year of life. In New York City where the incidence was very low, cases were scattered with little variation in incidence among children up to 10 years of age.

\section{SEX INCIDENCE}

There was an approximately equal sex distribution of positive cases up to 14 years of age, but there was a significant excess in the male cases under 1 year of age in the culture-negative series (table 6). At ages 15 to 44 , there was a preponderance of females in both groups. (The informants usually were women.) There were 117

TABLE 6.-Reported and discovered cases of acute diarrhea, by age and sex, in families with cases culture positive for Shigella, and in those with culture negative cases only

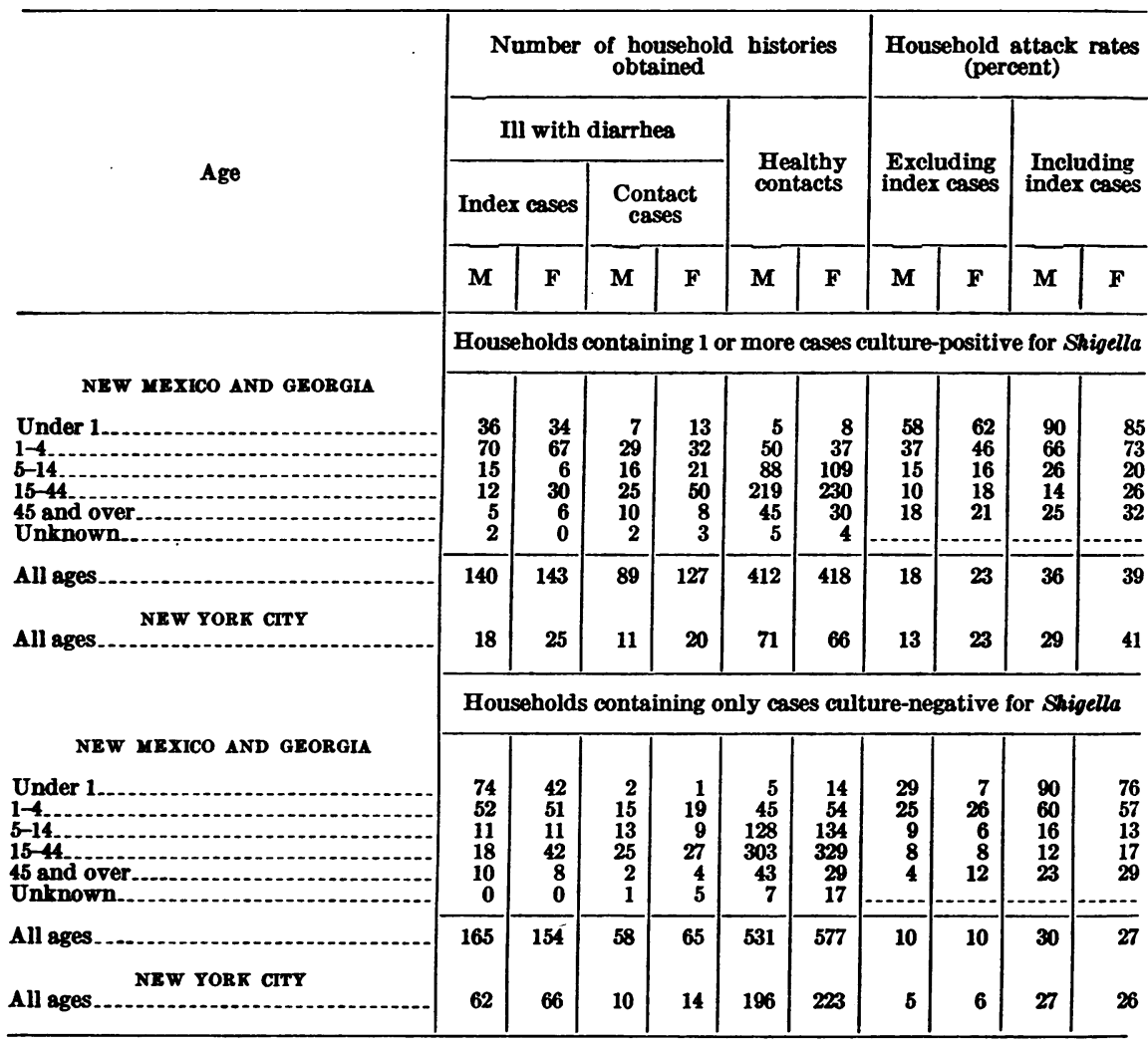

cases within this age group in New Mexico and Georgia in families with cases culturally positive for Shigellae; 80 (68 percent) were females. Of the corresponding 112 cases in families in which all cases were culture-negative for Shigellae, 69 (62 percent) were females. The excess was most marked at ages 20 to 34 years. The observations in New York did not provide significant variations. 


\section{HOUSEHOLD ATTACK RATES}

The attack rates for acute diarrhea in affected households (excluding and including the index cases) are given by age and sex in table 6 . In "positive families," - those with a proved case of clinical shigellosis-the secondary attack rates were highest in the young, and in New Mexico and Georgia the rate declined from a total of 61 percent in the first year of life to 16 percent at ages 5 to 14 years. The rates were at about this level in older age groups. The corresponding figures for the negative families were consistently lower.

Only a small number of the infants in families with acute diarrhea remained free of this disorder and the rates were lhigh for children from 1 to 4 years. Secondary and total household attack rates were closely similar in all areas, even though the prevalence of diarrheal diseases in the general population varied widely.

TABLE 7.-Secondary attack rates, by race and area, in families with cases of acute diarrhea, according to culture findings in the households

\begin{tabular}{|c|c|c|c|c|c|c|c|c|}
\hline \multirow{4}{*}{ Race and area } & \multicolumn{4}{|c|}{ "Positive households" 1} & \multicolumn{4}{|c|}{ "Negative households" } \\
\hline & \multirow{3}{*}{$\begin{array}{l}\text { Index } \\
\text { cases }\end{array}$} & \multicolumn{3}{|c|}{ Contacts } & \multirow{3}{*}{$\begin{array}{l}\text { Index } \\
\text { cases }\end{array}$} & \multicolumn{3}{|c|}{ Contacts } \\
\hline & & \multirow{2}{*}{ Total } & \multicolumn{2}{|c|}{ IIl } & & \multirow{2}{*}{ Total } & \multicolumn{2}{|c|}{ III } \\
\hline & & & Number & Percent & & & Number & Percent \\
\hline NEW MEXICO & & & & & & & & \\
\hline $\begin{array}{l}\text { Anglo-American } \\
\text { Spanish-American } \\
\text { Indian }\end{array}$ & $\begin{array}{r}101 \\
110 \\
21\end{array}$ & $\begin{array}{r}324 \\
447 \\
93\end{array}$ & $\begin{array}{r}105 \\
66 \\
18\end{array}$ & $\begin{array}{l}32 \\
15 \\
19\end{array}$ & $\begin{array}{r}127 \\
109 \\
14\end{array}$ & $\begin{array}{r}418 \\
435 \\
78\end{array}$ & $\begin{array}{r}56 \\
22 \\
3\end{array}$ & $\begin{array}{r}13 \\
5 \\
4\end{array}$ \\
\hline Total... & 232 & 864 & 189 & 22 & 250 & 231 & 81 & 9 \\
\hline GEORGIA & & & & & & & & \\
\hline $\begin{array}{l}\text { White } \\
\text { Negro }\end{array}$ & $\begin{array}{l}25 \\
26 \\
\end{array}$ & $\begin{array}{r}73 \\
109 \\
\end{array}$ & $\begin{array}{l}16 \\
11 \\
\end{array}$ & $\begin{array}{l}22 \\
10 \\
\end{array}$ & $\begin{array}{l}37 \\
32 \\
\end{array}$ & $\begin{array}{l}162 \\
138 \\
\end{array}$ & $\begin{array}{l}30 \\
12 \\
\end{array}$ & $\begin{array}{r}19 \\
9 \\
\end{array}$ \\
\hline Total_.............. & 51 & 182 & 27 & 15 & 69 & 300 & 42 & 14 \\
\hline $\begin{array}{l}\text { NEW YORK } \\
\text { White } \\
\text { Negro }\end{array}$ & $\begin{array}{l}29 \\
14\end{array}$ & $\begin{array}{r}106 \\
62\end{array}$ & $\begin{array}{l}18 \\
13\end{array}$ & $\begin{array}{l}17 \\
21\end{array}$ & $\begin{array}{l}92 \\
36\end{array}$ & $\begin{array}{l}314 \\
129\end{array}$ & $\begin{array}{r}18 \\
6\end{array}$ & $\begin{array}{l}6 \\
5\end{array}$ \\
\hline Total_................. & 43 & 168 & 31 & 18 & 128 & 443 & 24 & 5 \\
\hline
\end{tabular}

1 Households in which one case or more of acuate diarrhea was found positive for Shigella.

2 Households in which all cases of acute diarrhea were culture-negative for Shigella.

Differences by race and area (table 7) show that the secondary attack rates for the Anglo-Americans and the whites were higher than those for the Spanish-Americans and Negroes in the respective areas. Mortality data indicate, however, that diarrheal diseases are more serious among Spanish-American and Negroes than among the Anglo-Americans. An exact uniformity of reports from these different racial groups could not be assured. Language difference made it more difficult to obtain histories from the Spanish-speaking and 
Indian families than from the Anglo-Americans in New Mexico. Also, where diarrhea was of common occurrence, little attention was paid to the milder disorders, which probably were often unknown to the informant or forgotten by the patient. Where these disorders wer rare, the mild attacks, since they were unusual, would be recalled and reported. These factors were recognized in the beginning and every effort was made to minimize their influence. We do not believe that they played an important role in Georgia (where such artificial variations should be small) since the whites had a secondary attack rate more than twice that of the Negroes.

There were 216 secondary cases in the positive households in New Mexico and Georgia; 175 were examined culturally and 114 (65.2 percent) were positive (table 8). Often these were examined during

TABLE 8.-Results of single fecal cultures for Shigella on secondary cases and contacts found by epidemiological investigation of households having a culture positive Shigella case of acute diarrhea

\begin{tabular}{|c|c|c|c|c|c|c|}
\hline \multirow{3}{*}{ Age } & \multicolumn{3}{|c|}{$\begin{array}{c}\text { Contacts with history of } \\
\text { diarrhea }\end{array}$} & \multicolumn{3}{|c|}{$\begin{array}{l}\text { Contacts without history of } \\
\text { diarrhea }\end{array}$} \\
\hline & \multirow{2}{*}{$\begin{array}{l}\text { Number } \\
\text { cultured }\end{array}$} & \multicolumn{2}{|c|}{ Shigella isolated } & \multirow{2}{*}{$\begin{array}{l}\text { Number } \\
\text { cultured }\end{array}$} & \multicolumn{2}{|c|}{ Shigella isolated } \\
\hline & & Number & Percent & & Number & Percent \\
\hline $\begin{array}{l}\text { Under } 1 \\
1-4 \\
5-14 \\
15-14 \\
\text { 45 and over } \\
\text { Unknown }\end{array}$ & $\begin{array}{r}19 \\
54 \\
30 \\
53 \\
17 \\
2\end{array}$ & $\begin{array}{r}13 \\
43 \\
18 \\
31 \\
8 \\
1\end{array}$ & $\begin{array}{l}68 \\
80 \\
60 \\
53 \\
47 \\
50\end{array}$ & $\begin{array}{r}6 \\
27 \\
59 \\
107 \\
\hdashline\end{array}$ & $\begin{array}{r}0 \\
6 \\
12 \\
19 \\
\hdashline \\
\hdashline\end{array}$ & $\begin{array}{r}0 \\
22 \\
20 \\
18 \\
\hdashline \\
\hdashline\end{array}$ \\
\hline Total & 175 & 114 & 65 & 199 & 37 & 19 \\
\hline
\end{tabular}

convalescence or after recovery, and the percentage of individuals with proved infections is strong evidence that a very high proportion of these secondary illnesses were due to Shigella.

The findings on a single culture examination of each of 199 healthy contacts of known positive cases are given in table 8 . Nineteen percent of the health contacts were found to be passive carriers.

There were 1,329 persons in the 283 positive families in New Mexico and Georgia. The proved positive individuals included 261 index cases, 114 contact cases, and 37 passive carriers-a total of 412 (31 percent). The unexamined contacts included 41 who became ill and 631 who did not. Assuming that there would have been the same proportion of positive observations among these had they been examined, there would be an additional 27 positive cases and 117 passive carriers. Adding these to the proved infected individuals there would be 261 positive index cases, 141 positive contact cases, and 154 passive carriers, in all 556 (41.8 percent) infected of the 1,329 family members. The observed and computed prevalence rates given above were based largely on single cultural tests. If these had been repeated and 
continued through a period adequate to indicate incidence rates, it seems certain that the majority of the household contacts of shigellosis would have been found infected.

\section{SEASONAL DISTRIBUTION}

Our data on seasonal distribution are incomplete because of the interrupted operation of our laboratory and transfers from one study area to another. Available information on clinical cases is given in table 9. The seasonal variation in incidence was marked in $\mathrm{New}$ Mexico and Georgia, but was less marked in New York. The summer rise was earlier in Georgia than in New Mexico. The seasonal distribution of the culturally positive and negative cases was similar.

TABLE 9.-The observed seasonal distribution of acute diarrheal disease, by area and cultural findings

\begin{tabular}{|c|c|c|c|c|c|c|c|c|c|c|c|c|}
\hline \multirow{4}{*}{ - } & \multicolumn{12}{|c|}{ Number and percentage of cases by month of onset } \\
\hline & \multicolumn{4}{|c|}{ New Mexico } & \multicolumn{4}{|c|}{ Georgia } & \multicolumn{4}{|c|}{ New York } \\
\hline & \multicolumn{2}{|c|}{ Positive } & \multicolumn{2}{|c|}{ Negative } & \multicolumn{2}{|c|}{ Positive } & \multicolumn{2}{|c|}{ Negative } & \multicolumn{2}{|c|}{ Positive } & \multicolumn{2}{|c|}{ Negative } \\
\hline & Num- & $-\begin{array}{l}\text { Per- } \\
\text { cent }\end{array}$ & Num- & $\begin{array}{l}\text { Per- } \\
\text { cent }\end{array}$ & Num. & - $\begin{array}{l}\text { Per- } \\
\text { cent }\end{array}$ & Num: & Per- & Num- & $\begin{array}{l}\text { Per- } \\
\text { cent }\end{array}$ & Num- & $\begin{array}{l}\text { Per- } \\
\text { cent }\end{array}$ \\
\hline $\begin{array}{l}\text { January } \\
\text { February } \\
\text { March } \\
\text { April } \\
\text { May. } \\
\text { June } \\
\text { July } \\
\text { August } \\
\text { September. } \\
\text { October } \\
\text { November } \\
\text { December }\end{array}$ & $\begin{array}{r}8 \\
12 \\
12 \\
12 \\
12 \\
20 \\
95 \\
55 \\
24 \\
18 \\
6 \\
2\end{array}$ & $\begin{array}{r}3.4 \\
.8 \\
.8 \\
.8 \\
.8 \\
8.5 \\
40.3 \\
23.3 \\
10.3 \\
7.6 \\
2.6 \\
.8 \\
\end{array}$ & $\begin{array}{ll}10 \\
1 & 0 \\
1 & 0 \\
1 & 0 \\
1 & 1 \\
22 \\
92 \\
48 \\
29 \\
18 \\
15 \\
3\end{array}$ & $\begin{array}{l}4.2 \\
0 \\
0 \\
0 \\
.4 \\
9.2 \\
38.6 \\
20.2 \\
12.2 \\
7.6 \\
6.3 \\
1.3\end{array}$ & $\begin{array}{r}0 \\
0 \\
1 \\
1 \\
14 \\
10 \\
9 \\
1 \\
1 \\
1 \\
0 \\
0\end{array}$ & $\begin{array}{l}0 \\
0 \\
2.7 \\
2.7 \\
36.8 \\
26.3 \\
23.4 \\
2.7 \\
2.7 \\
2.7 \\
0 \\
0\end{array}$ & $\begin{array}{r}3 \\
3 \\
3 \\
4 \\
14 \\
18 \\
6 \\
2 \\
2 \\
2 \\
0 \\
0\end{array}$ & $\begin{array}{r}5.3 \\
5.3 \\
5.3 \\
7.0 \\
24.5 \\
31.6 \\
10.5 \\
3.5 \\
3.5 \\
3.5 \\
0 \\
0\end{array}$ & $\begin{array}{r}6 \\
11 \\
10 \\
11 \\
6 \\
10 \\
6 \\
8 \\
19 \\
8 \\
9 \\
6\end{array}$ & $\begin{array}{r}7.5 \\
1.3 \\
0 \\
1.3 \\
7.5 \\
12.5 \\
7.5 \\
10.0 \\
23.7 \\
10.0 \\
11.2 \\
7.5\end{array}$ & $\begin{array}{r}8 \\
10 \\
10 \\
11 \\
2 \\
24 \\
25 \\
66 \\
26 \\
34 \\
13 \\
10\end{array}$ & $\begin{array}{r}3.8 \\
0 \\
0 \\
.5 \\
1.0 \\
11.5 \\
12.0 \\
31.5 \\
12.4 \\
16.3 \\
6.2 \\
4.8\end{array}$ \\
\hline Total & 236 & 100.0 & 238 & 100.0 & 38 & 100.0 & 57 & 100.0 & 80 & 100.0 & 209 & 100.0 \\
\hline
\end{tabular}

1 Incomplete data.

\section{MANIFEST SOURCES OF CONTACT}

A manifest source is defined here as any clinical case or cases occurring currently or in the preceding month with which the individual might have had direct or indirect contact. Such sources included preceding cases in the household and in the immediate neighborhood, or those known to have been encountered elsewhere. A majority of the positive index cases ( 80 percent in New York, 72 percent in Georgia and 56 percent in New Mexico) occurred as isolated infections unrelated to any manifest source insofar as could be determined by inquiry.

The following observation and comment reported in XIII of this series warrants repetition. "Of the 380 culture-positive persons en- 
countered in these surveys of general population groups only 2 were under the care of a physician. One case acutely ill when found on the survey was admitted to the hospital the following day and died 2 days later. Without a special study, only these 2 would have been tested culturally, and thus there would have been 2 demonstrated and 378 undetected infectious with Shigellae. Thus, for every known infection (manifest source) there are numerous unrecognized infections (hidden source). In the light of these findings it is not surprising that endemic diarrheal diseases commonly appear to be scattered sporadic cases. These seemingly unrelated infections may arise from a single source or be joined by a series of undetected infections. This knowledge is essential for the interpretation of the epidemiology, of the acute diarrheal diseases."

\section{POSSIBLE MODES OF SPREAD}

All of our household studies included descriptions of water supply, excreta disposal, food including milk, housing, fly prevalence, and general hygiene. In addition special sanitary surveys were made in the various areas. These data have been analyzed and compared, and a summary of the findings is presented below.

Water.-Water supplies varied from well managed presumably safe public supplies to open surface wells and irrigation ditches. The wells often were hazardously close to unsanitary privies and had defective superstructures. The water supply to certain of the Indian pueblos was provided from satisfactory Government-built deep wells. Cases occurred with equal frequency in groups, otherwise comparable, using public water systems and in those using unsafe well water. Good wells in the Indian pueblos did not result in a low rate of diarrheal disorders. Shigellosis spread readily among inmates of institutions having a sanitary water supply. Institutional outbreaks were ordinarily limited in distribution with heavily infected groups and uninfected groups using water from a common source. We found no evidence that contaminated water was responsible for the outbreaks observed in military units.

Excreta disposal.-Shigella infections were slightly more common in homes having a privy than in those with a flush toilet. The significance of the change from defective to satisfactory outhouses was studied in one community. The incidence of diarrheal diseases was less in the 2 years after the installation of sanitary privies as compared with the preceding year. In these later years, though the infection was introduced to the community, there was no evidence of any wide dissemination such as was observed repeatedly in other semirural unsanitated neighborhoods. All institutional and military groups involved in an outbreak of shigellosis were supplied with flush toilets or sanitary privies. 
Food.-No evidence was found to indicate that milk supplies were important in the spread of the observed cases. In New Mexico canned milk was used more commonly in families with infection than in the general population. This was the usual source of milk for the Indians among whom the diarrheal diseases were very prevalent. In Georgia, raw and canned milk was used with equal frequency by the positive and negative households and cases; in New York City canned and pasteurized milk exclusively was purchased in the households studied. The milk served in institutions and military units was pasteurized, canned, or dried.

It was commonly found the patient blamed one or another seasonal fruit or vegetable for an attack of diarrhea. Our data indicate that, in general, consumption of these foodstuffs was coincidental rather than causative in the case of the proved Shigella infections as well as in the negative endemic diarrheal disorders. We did not obtain any information about the possible role of various meats in the spread of endemic salmonellosis.

Twenty-six outbreaks of shigellosis were investigated in these studies. Only one of these epidemics, reported in IV of this series, was traced to an infected food supply. Some supplementary spread by way of food handlers was noted in two other epidemics. In these, infected food played only a minor role in the transmission of the infection. This was in spite of the fact that food handlers were as commonly found infected as other groups in the general population.

Flies.-The cases, and particularly the positive ones in New Mexico, occurred most commonly where flies were prevalent. On the other hand, they occurred in New York in the absence of flies. A high prevalence and active spread of shigellosis was observed in institutional and military groups when there were no flies.

Laboratory tests on the fly did not provide any strong indication of its danger. Only one isolation of Shigella was made in 112 attempts with pooled specimens of flies. A majority of the flies were caught in the dysentery ward of the mental hospital in Puerto Rico. These flies had easy access to heavily positive excreta, since a shortage of attendants made adequate sanitation an impossibility. Flies were swatted in the ward, immediately transferred to nutrient broth and then subcultured on SS agar. Under these circumstances, the failure to isolate Shigellae was impressive.

General and personal cleanliness. - Diarrheal disorders were particularly common in homes rated as defective in general cleanliness. The institutional inmates usually involved in Shigella outbreaks were those with the poorest habits of personal cleanliness. In military units more than 10,000 survey cultures were taken by rectal swabs. On taking these we recorded all instances in which there was gross fecal 
contamination in the anal region. The prevalence of Shigella infection was more than 15 percent in three of the units; here over twothirds of the men had visible fecal material in the anal region. The prevalence of infection was 5 percent in another camp; here one-third had evidence of fecal soiling as above. The prevalence of shigellosis was less than 2 percent in the other groups studied; less than 10 percent and usually less than 5 percent of the men examined showed gross fecal contamination.

The possible role of contaminated fingers in the spread of Shigella infections was examined by laboratory methods. A wide-mouthed specimen bottle with nutrient lactose broth and a fermentation tube were used. The tips of the fingers of each hand were dipped and rinsed in the culture medium. Immediately thereafter material from under the nails was scraped into the broth by a sterile nail file. After 6 and 18 hours incubation S. S. agar was streaked. Eosin methylene-blue agar was also inoculated at 18 hours. A total of 268 finger and fecal cultures were obtained concurrently, and Shigellae were isolated by fecal culture from 39 and by finger cultures from 4 (10 percent) of those with positive stool findings. Fecal cultures were negative in 229, but Shigellae were isolated by finger cultures from 2 of this group (1 percent). Tests for Escherichia coli were completed in 235 of the finger cultures and were positive in 192 (82 percent). The individuals tested were inmates of a mental hospital. They did not include either the excited or untidy patients. They had ready access to the wash room and showers and used them freely.

Economic status and crowding.-Diarrheal diseases were much more common in the poor families than in the well-to-do and were similarly associated with overcrowding.

Sanitary surveys of the general population in New Mexico showed that 20 percent of the homes had two or more persons per room. This degree of overcrowding was found in 49 percent of the families with cases of diarrhea positive for Shigellae. In Georgia overcrowding of this type was found in 51 percent of the positive households and in 30 percent of those with negative cases only. The element of overcrowding was also present in military and institutional groups studied.

The evidence obtained relative to possible modes of spread of Shigella infection and other diarrheal diseases may be summarized as follows.

No evidence was found of dissemination of these diseases through water or milk. Other foodstuffs were rarely indicted in the endemic disorders and even less frequently convicted. Epidemics, particularly of salmonellosis, were found which were food-borne. The exact importance of this mode of spread could not be assessed with certainty; the striking feature however was the lack of substantial incriminating evidence. 
The presence of flies, improper excreta disposal, bad personal hygiene, overcrowding, and bad habits of personal hygiene were all associated with an excess of diarrheal disorders. The relative importance of these factors could not be determined from our data. It is certain that Shigella infections spread easily in crowded groups in the absence of flies. The evidence obtained in institutional and military groups indicated that bad personal hygiene in these groups was most important. Further study is needed however to determine the specific role of insects in the spread of these infections.

\section{SUMMARY}

1. The epidemiology of the acute diarrheal diseases was studied in New Mexico, Georgia, New York, and Puerto Rico.

2. The recent reported mortality from diarrheal diseases in these areas varied from more than 400 to less than 5 deaths per 100,000 population per annum.

3. Seventy-five percent of the children who died from diarrheal diseases in New Mexico and Georgia were found, by the culture method, to be positive for Shigella.

4. The discovered morbidity from these infections varied according to the method used in collecting data. The rates were comparatively low when reported cases were considered but were high when intensive case-finding procedures were used. The morbidity from culturenegative diarrheal disorders varied similarly.

5. Subclinical shigellosis was identified frequently.

6. Shigella infections in infants and young children were often serious or fatal diseases; older children had milder clinical attacks and many subclinical infections; adolescents and adults most commonly had subclinical attacks.

7. The total attack rates, including clinical and subclinical infections, were relatively constant from ages 1 to 9 years and at a higher level than those for infants, adolescents, and adults.

8. There were only minor variations in incidence by sex.

9. Household attack rates were high, and varied inversely with the general incidence of diarrheal disease in the population group.

10. The incidence of these diseases was high in summer and low in winter.

11. Cases of acute diarrhea due to Shigella in the general population occurred chiefly as isolated infections, unrelated to other manifest sources.

12. There was strikingly little evidence that these enteric infections were disseminated by water, milk, or other food. Finger contamination and relatively direct person-to-person spread appeared to be chiefly 
responsible for the dissemination of these infections in institutional and military groups. Flies, combined with defective excreta dispesal, were potential means of spread, but our data did not provide an exact measure of their importance.

\section{REFERENCES}

Other papers in the series, Studies of the Acute Diarrheal Diseases, are:

I. Hardy, A. V., Watt, J., DeCapito, T. M., and Kolodny, M. H.: Differential culture media. Pub. Health Rep. 54: 287 (1939).

II. Spector, B. K., Hardy, A. V., and Mack, M. G.: Parasitological observations. Pub. Health Rep. 54: 1105 (1939).

III. Hardy, A. V.; Watt, J.; Kolodny, M. H., and DeCapito, T. M.: Infections due to the "Newcastle dysentery bacillus." Am. J. Pub. Health. 30: 53 (1940).

IV. Hardy, A. V., Frant, S., Jarcho, S. W., and Schlosser, E. G.: An outbreak of bacillary dysentery due to the "Newcastle dysentery bacillus." Pub. Health Rep. 55: 2101 (1940).

V. Mosher, W. E., Jr., Wheeler, S. M., Chant, H. L., and Hardy, A. V.: An outbreak due to Salmonella typhi murium. Pub. Health Rep. 56: 2415 (1941).

VI. Hardy, A. V., Watt, J., and DeCapito, T. M.: New procedures in bacteriological diagnosis. Pub. Health Rep. 57: 521 (1942).

VII. Watt, J., Hardy, A. V., and DeCapito, T. M.: Carriers of Shigella dysenteriae. Pub. Health Rep. 57: 524 (1942).

VIII. Hardy, A. V., Watt, J., Peterson, James, Peterson, Jerome, and Schlosser, E.: Sulfaguanidine in the control of Shigella dysenteriae infections. Pub. Health Rep. 57 : 529 (1942).

IXA. Hardy, A. V., Shapiro, R. L., Chant, H. L., and Siegel, M.: Shigella dysenteriae infections among institutional inmates. Pub. Health Rep. 57: 1079 (1942). IXB. Watt, J., Hardy, A. V., and DeCapito, T. M.: Shigella dysenteriae infections among institutional inmates. Pub. Health Rep. 57: 1095 (1942).

XA. Hardy, A. V., Burns, W., and DeCapito, T. M.: Cultural observations on the relative efficacy of sulfonamides in Shigella dysenteriae infections. Pub. Health Rep. 58: 689 (1943).

XB. Hardy, A. V., and Cummins, S. D.: A preliminary note on the clinical response to sulfadiazine therapy. Pub. Health Rep. 58: 693 (1943).

XC. Hardy, A. V.: Further cultural observations on the relative efficacy of sulfonamides in Shigella infections. Pub. Health Rep. 60: 1037 (1945).

XD. Watt, J., and Cummins, S. D.: Further studies on the relative efficacy of sulfonamides in shigellosis. Pub. Health Rep. 60: 1355 (1945).

XI. Hardy, A. V., Watt, J., and DeCapito, T. M.: The typing of Shigella dysenteriae Flexner. Pub. Health Rep. 58: 696 (1943).

XII. Hardy, A. V., and Watt, J.: Etiology. Pub. Health Rep. 60: 57 (1945).

XIII. Watt, J., and Hardy, A. V.: Cultural surveys of normal population groups. Pub. Health Rep. 60: 261 (1945).

XIV. Hardy, A. V., and Watt, J.: Clinical observations. Pub. Health Rep. 60: 521 (1945).

XV. Watt, J., and DeCapito, T. M.: The agglutination test in Shigella paradysenteriae infections. Pub. Health Rep. 60: 642 (1945).

XVI. Watt, J., and Carlton, E.: An outbreak of Salmonella typhimurium infection among newborn premature infants. Pub. Health Rep. 60: 734 (1945).

XVII. Hardy, A. V.: The sulfonamides in shigellosis. Pub. Health Rep. 61: 857 (1946). 


\section{INCIDENCE OF DISEASE}

No health department, State or local, can effectively prevent or control disease without knowledge of when, where, and under what conditions cases are occurring

\section{UNITED STATES}

\section{REPORTS FROM STATES FOR WEEK ENDED FEBRUARY 28, 1948}

\section{Summary}

A total of 9,008 cases of influenza was reported, as compared with 11,234 last week and a 5-year (1943-47) median of 5,192. Of the 13 States reporting currently more than 80 cases (all in the South Atlantic, South Central, Mountain, and Pacific areas), only 5 showed increases-Virginia 556 to 768, West Virginia 82 to 178 , Oklahoma 84 to 357 , Utah 80 to 151 , and Oregon 635 to 798 . Of the current total, 9 States, all in the above-mentioned areas, reported an aggregate of 7,884 cases (88 percent). Of the 92,191 cases reported for the year to date, 7 States have reported 79,062 cases ( 86 percent), as follows: Virginia 7,212, South Carolina 8,629, Alabama 4,512, Arkansas 4,155, Texas 36,537, Arizona 8,524, California 9,493. The total number of cases reported during the 30 -week period since the average date of seasonal low incidence is 135,749 , as compared with 65,592 for the same period last year, which was the lowest number for a corresponding period of the past 5 years, and 642,347 , the highest, in 1943-44, and a 5-year median of 65,830 .

The total of 20 cases of poliomyelitis reported (no State reporting more than 3 cases) is less than reported for any corresponding week since 1943 (15 cases).

Indiana, Nebraska, and Kansas each reported 1 case of smallpox. The cumulative figure for smallpox for the year to date is 25 , as compared with 30 for the same period last year and a 5-year median of 77. New Jersey and Pennsylvania each reported 1 case of anthrax, and California 1 case of leprosy.

Deaths recorded during the week in 93 large cities of the United States totaled 9,765, as compared with 10,655 last week, 10,165 and 10,390 , respectively, for the corresponding weeks of 1947 and 1946, and a 3-year (1945-47) median of 10,165. The total for the 9 weeks ended February 28 is 93,716 , as compared with 89,943 for the corresponding period last year. Infant deaths during the week in the same cities totaled 600, as compared with 776 last week, 796 for the same week last year, and a 3-year median of 689 . The cumulative figure is 6,416 , as compared with 7,377 for the corresponding period last year. 
Telegraphic morbidity reports from State health officers for the week ended Feb. 28, 1948, and comparison with corresponding week of 1947 and 5-year median

In these tables a zero indicates a definite report, while leaders imply that, although none was reported, cases may have occurred.

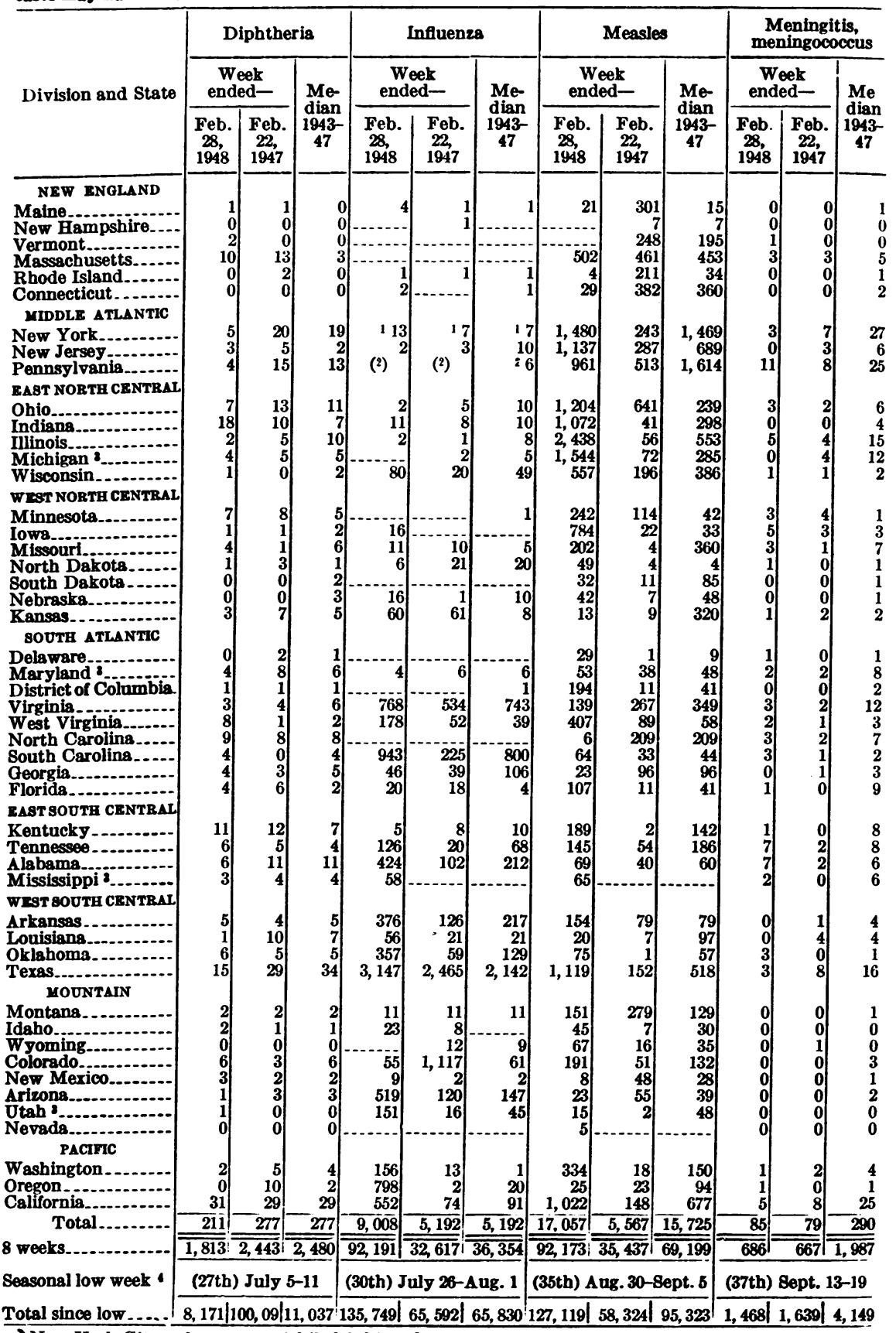

1 New York City only. 2 Philadelphia only. Period ended earlier than Saturday.

- Dates between which the approximate low week ends. The specific date will vary from year to year. 
Telegraphic morbidity reports from State health officers for the week ended Feb. 28, 1948, and comparison with corresponding week of 1947 and 5-year median-Con.

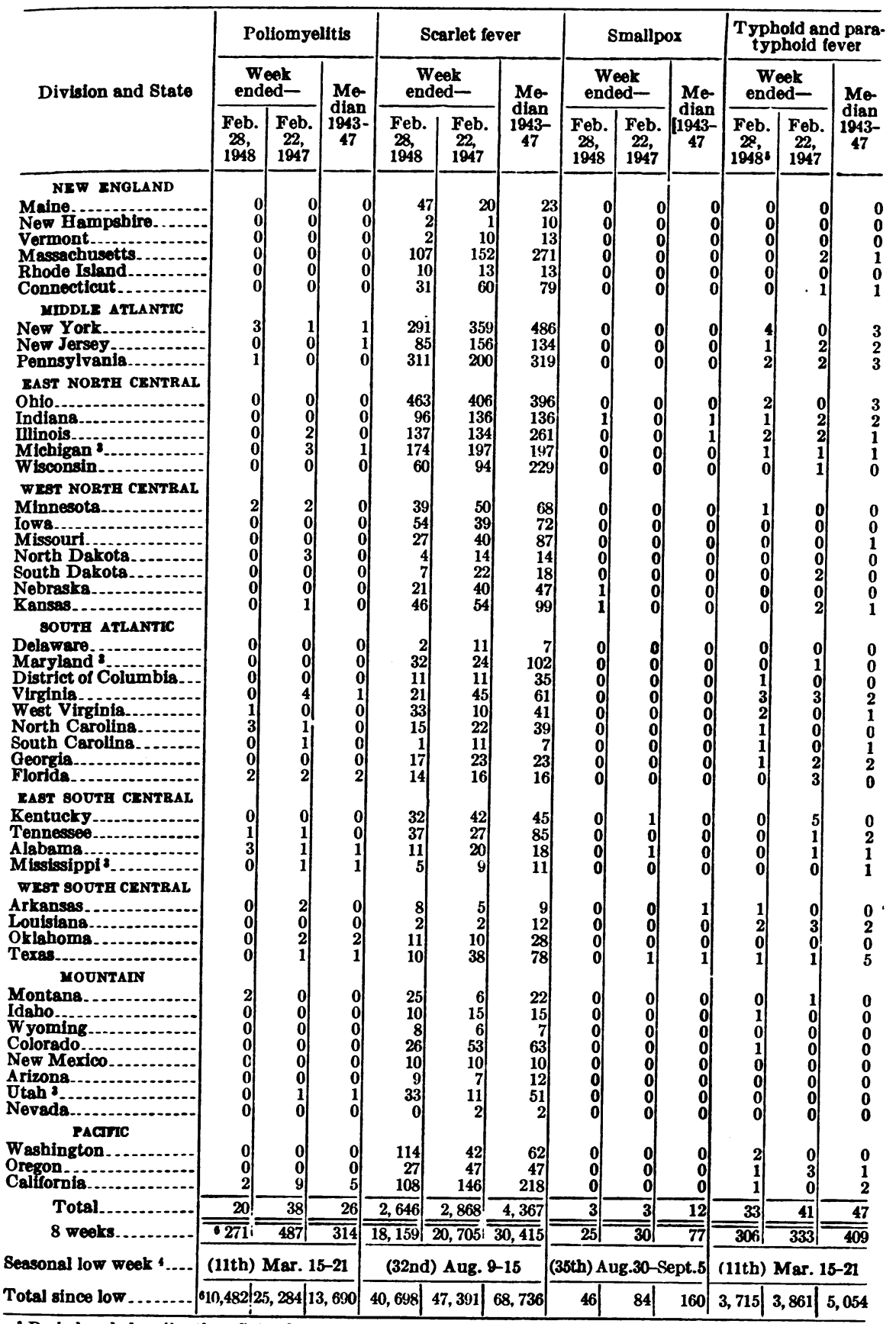

3 Period ended earlier than Saturday.

4 Dates between which the approximate low week ends. The specific date will vary from year to year.

Including paratyphoid fever reported separately, as follows: New York 1, Pennsylvania 1 (salmonella infection), Virginia 1, North Carolina 1, Washington 2 (salmonella infection)

of Correction (deducted from cumulative totals): Poliomyelitis, Indiana week ended Feb. 7, 1 case (instead
(ind 
Telegraphic morbidity reports from State health officers for the week ended Feb.28, 1948 , and comparison with corresponding week of 1947 and 5-year median-Con.

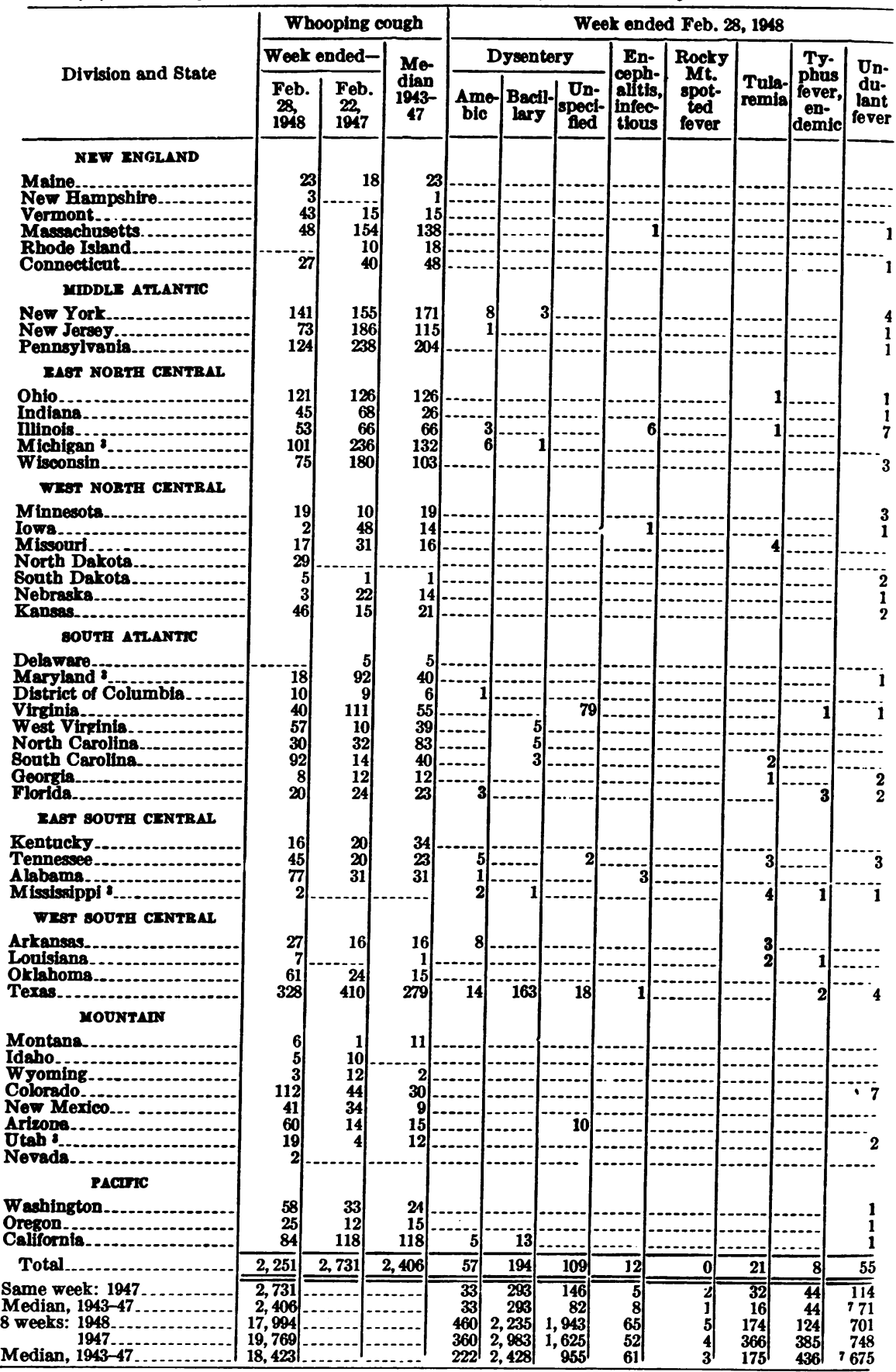

2 Period ended earlier than Saturday.

7 3-year median 1945-47.

Actinomycosis: South Dakota 2. Anthrax: New Jersey 1, Pennsylvania 1. Leprosy: California 1. Territory of Hawaii: Amebic dysentery 1, scarlet fever 1, whooping cough 16. 


\section{WEGKIY REPORTS FROM CIYIES*}

\section{City reports for week ended February 21, 1948}

This table lists the reports from 89 cities of more than 10,000 population distributed throughout the United States, and represents a cross section of the current urban incidence of the diseases included in the table.

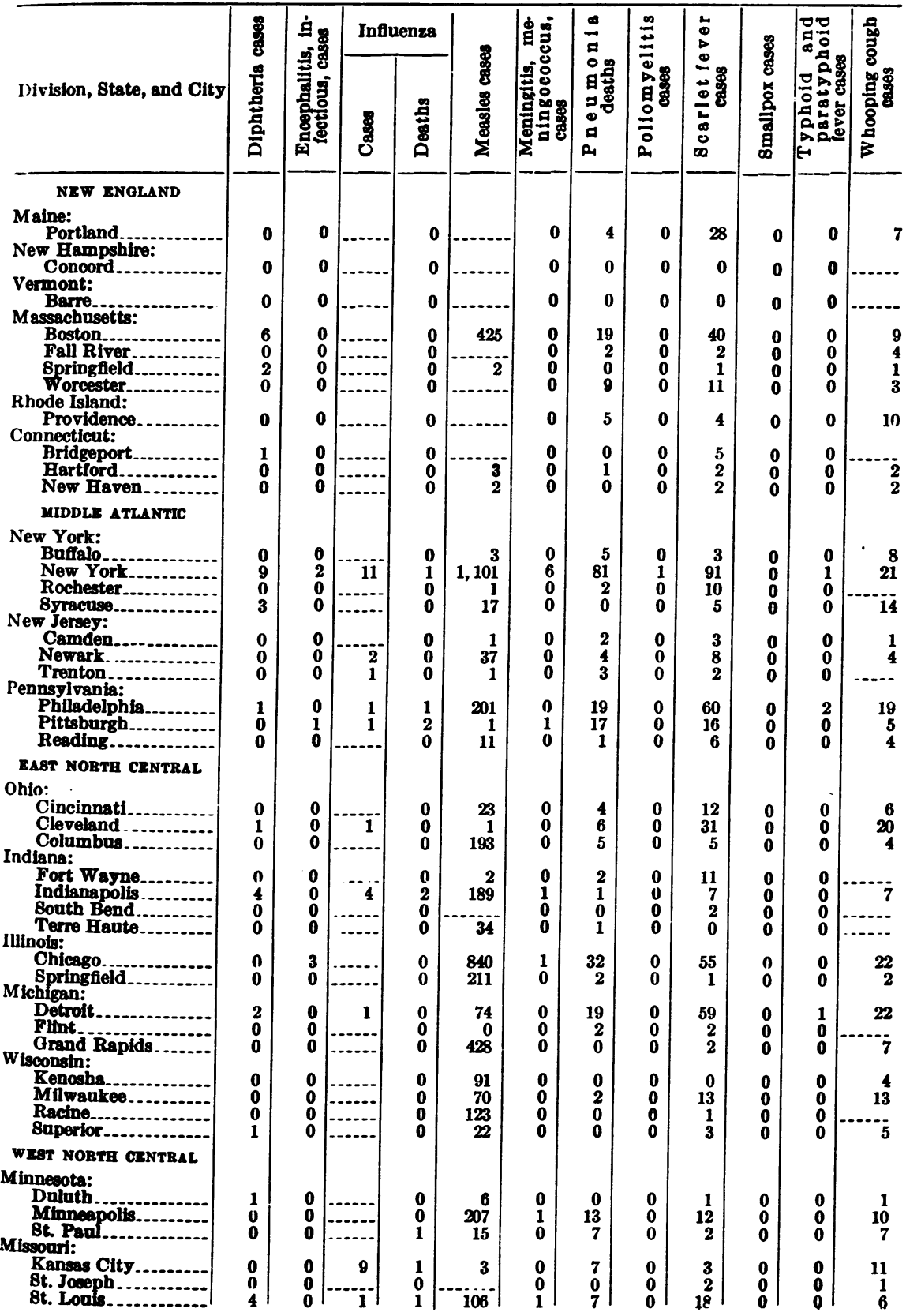

"In some instances the figures include nonresident cases 
City reports for week ended February 21, 1948-Continued

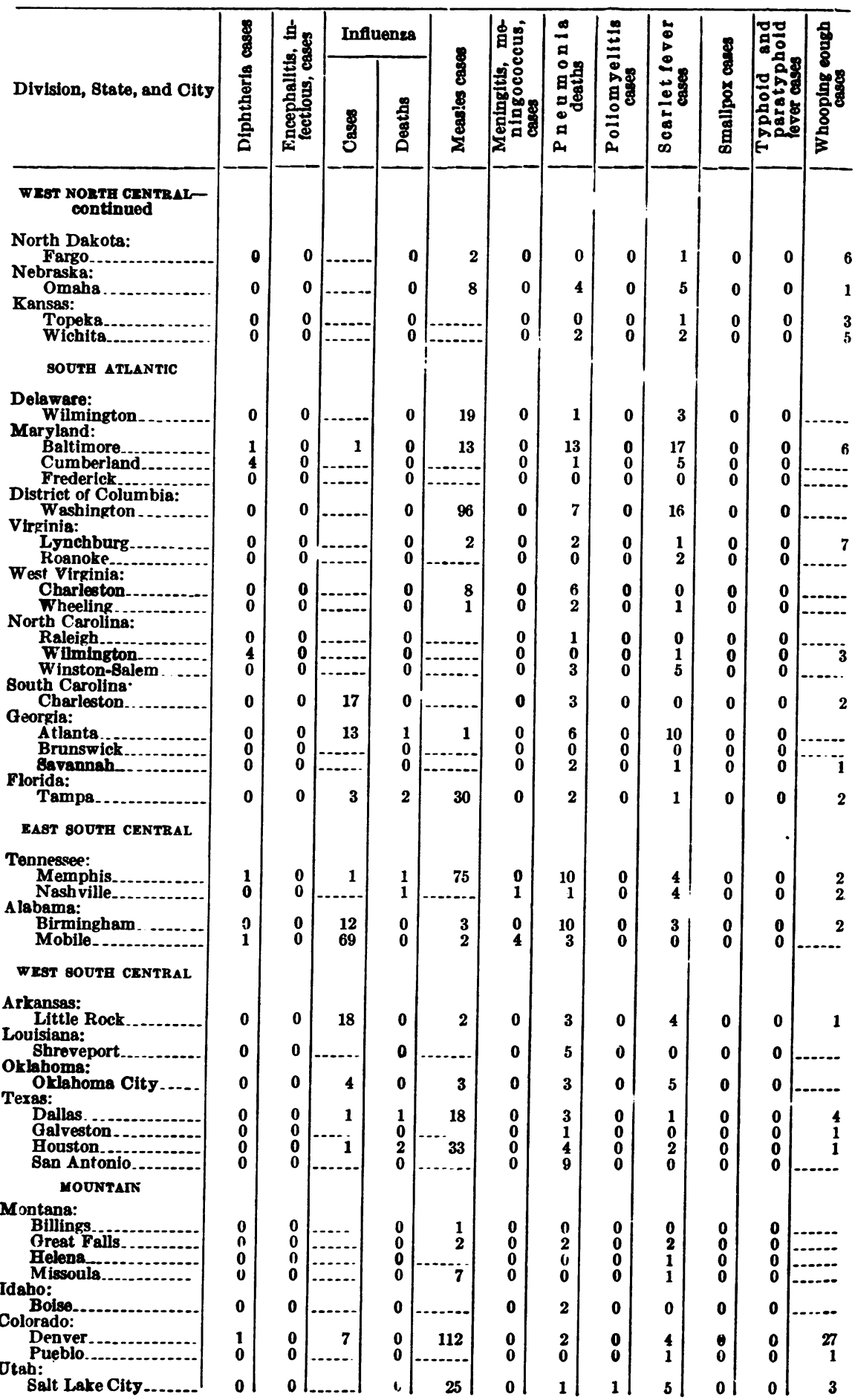


City reports for week ended February 21,1948 -Continued

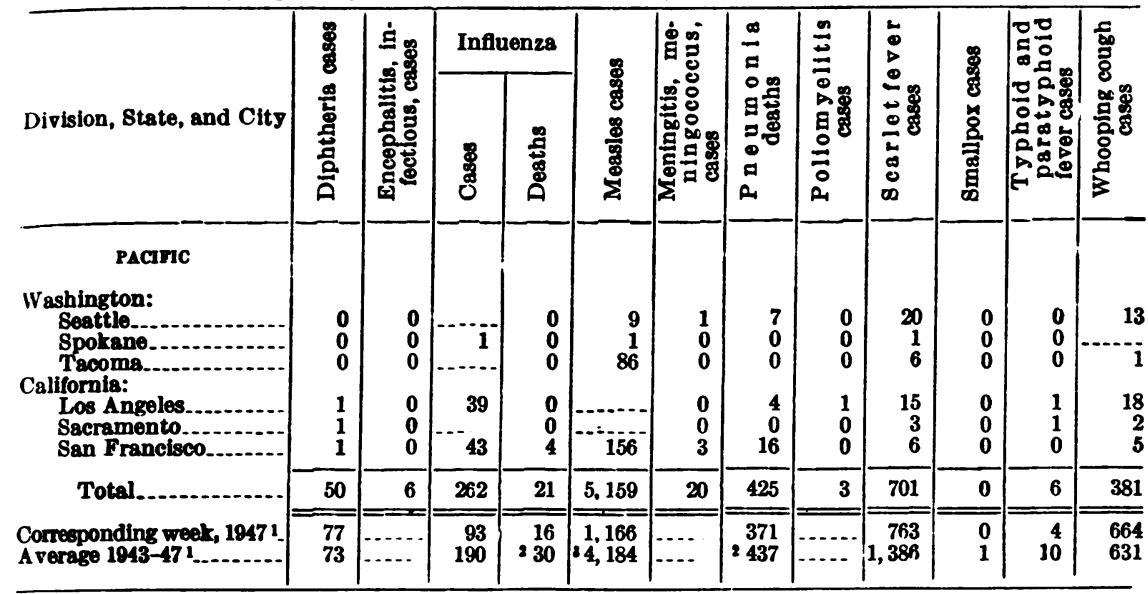

I Exclusive of Oklahoma City.

2 3-year average, $1945-1947$.

- 5-year median, 1943-47.

Rates (annual basis) per 100,000 population, by geographic groups, for the 89 cities in the preceding table (latest available estimated population, $33,896,900$ )

\begin{tabular}{|c|c|c|c|c|c|c|c|c|c|c|c|c|}
\hline & \multirow{2}{*}{ 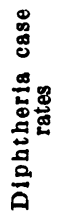 } & \multirow{2}{*}{ 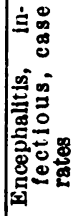 } & \multicolumn{2}{|c|}{ Influenza } & \multirow{2}{*}{ 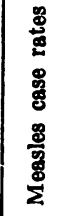 } & \multirow{2}{*}{ 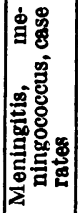 } & \multirow{2}{*}{ 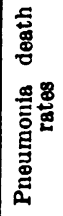 } & \multirow{2}{*}{ 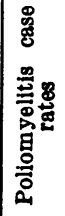 } & \multirow{2}{*}{ 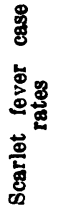 } & \multirow{2}{*}{ 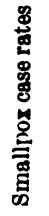 } & \multirow{2}{*}{ 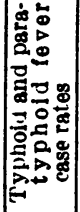 } & \multirow{2}{*}{ 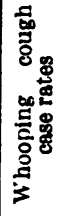 } \\
\hline & & & 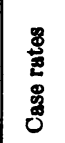 & 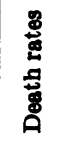 & & & & & & & & \\
\hline $\begin{array}{l}\text { New England } \\
\text { Middle Atlantic. } \\
\text { East North Central } \\
\text { West North Central. } \\
\text { South Atlantic } \\
\text { East South Central } \\
\text { West South Central } \\
\text { Mountain. } \\
\text { Pacific. }\end{array}$ & $\begin{array}{r}23.5 \\
6.0 \\
4.9 \\
9.9 \\
15.7 \\
11.8 \\
0.0 \\
7.9 \\
4.7\end{array}$ & $\begin{array}{l}0.0 \\
1.4 \\
1.8 \\
0.0 \\
0.0 \\
0.0 \\
0.0 \\
0.0 \\
0.0\end{array}$ & $\begin{array}{r}0.0 \\
7.4 \\
3.6 \\
19.9 \\
59.4 \\
484.0 \\
82.1 \\
55.6 \\
131.3\end{array}$ & $\begin{array}{r}0.0 \\
1.9 \\
1.2 \\
6.0 \\
5.2 \\
11.8 \\
10.3 \\
0.0 \\
6.3\end{array}$ & $\begin{array}{r}1,129 \\
636 \\
1,399 \\
690 \\
297 \\
472 \\
192 \\
1,168 \\
399\end{array}$ & $\begin{array}{r}0.0 \\
3.2 \\
1.2 \\
4.0 \\
0.0 \\
29.5 \\
0.0 \\
0.0 \\
6.3\end{array}$ & $\begin{array}{r}104.6 \\
62.0 \\
46.2 \\
79.6 \\
85.6 \\
141.6 \\
95.8 \\
55.6 \\
42.7\end{array}$ & $\begin{array}{l}0.0 \\
0.5 \\
0.0 \\
0.0 \\
0.0 \\
0.0 \\
0.0 \\
7.9 \\
1.6\end{array}$ & $\begin{array}{r}248 \\
94 \\
124 \\
94 \\
110 \\
65 \\
41 \\
111 \\
81\end{array}$ & $\begin{array}{l}0.0 \\
0.0 \\
0.0 \\
0.0 \\
0.0 \\
0.0 \\
0.0 \\
0.0 \\
0.0\end{array}$ & $\begin{array}{l}0.0 \\
1.4 \\
0.6 \\
0.0 \\
0.0 \\
0.0 \\
0.0 \\
0.0 \\
3.2\end{array}$ & $\begin{array}{r}99 \\
35 \\
68 \\
101 \\
37 \\
35 \\
24 \\
246 \\
62\end{array}$ \\
\hline Total. & 7.7 & 0.9 & 40.4 & 3.2 & 796 & 3.1 & 65.6 & 0.5 & 108 & 0.0 & 0.9 & 59 \\
\hline
\end{tabular}

Anthrax.-Cases: Philadelphia 3.

Dysenuery, amebic.-Cases: New York 5; Chicago 1; St. Louis 2; Los Angeles 2.

Dysentery, bacillary. -Cases: Worcester 1; Minneapolis 1; Los Angeles 5.

Leprosy. -Cases: New York 2; San Francisco 1.

Tularemia.-Cases: Memphis 1 .

Typhus fever, endemic.-Cases: New York 1.

\section{TERRITORIES AND POSSESSIONS}

\section{Hawaii Territory}

Plague (rodent).-During the month of January 1948, plague infection was reported found in 2 rats in Paia, Island of Maui, T. H., the last being found on January 15, 1948. Under date of February 27,1948 , plague infection was reported in a mass inoculation of tissue from 10 rats found in a gulch in Upper Paia, Island of Maui, and also in a mass inoculation of tissue from 9 rats found in Rainbow Park. Island of Maui, T. $\mathrm{H}$. 


\section{FOREIGN REPORTS}

\section{CANADA}

Provinces-Communicable diseases-Week ended February 7, 1948.Certain communicable diseases were reported by the Dominion Bureau of Statistics of Canada as follows:

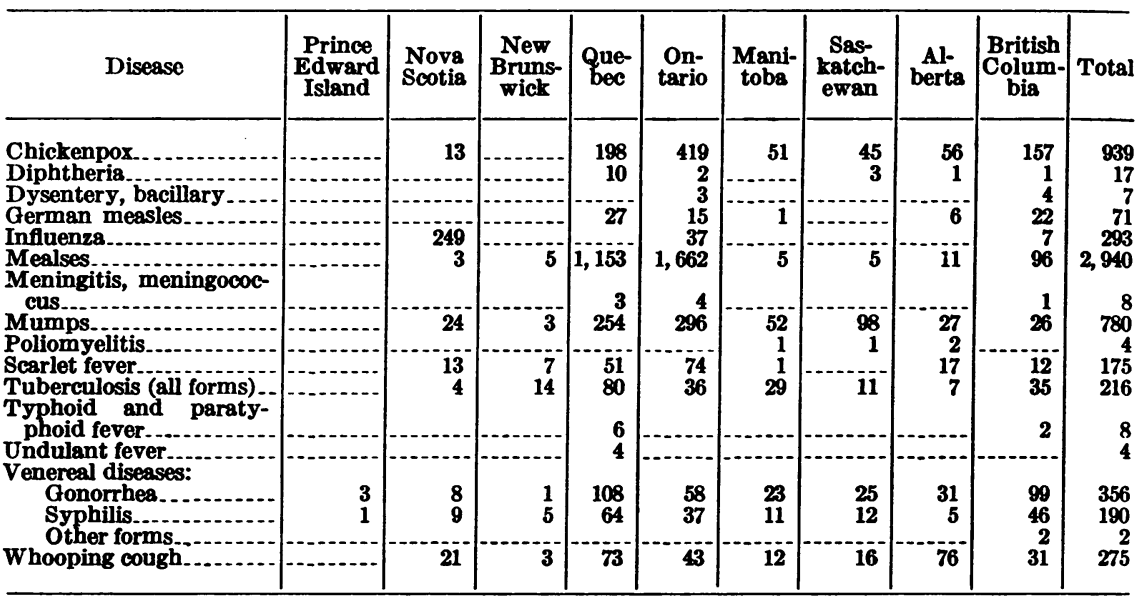

\section{NEW ZEALAND}

Notifiable diseases - 5 weeks ended January 3, 1948.-Certain notifiable diseases were reported in New Zealand as follows:

\begin{tabular}{|c|c|c|c|c|c|}
\hline Disease & Cases & Deaths & Disease & Cases & Deaths \\
\hline $\begin{array}{l}\text { Cerebrospinal meningitis } \\
\text { Diphtheria } \\
\text { Dysentery, bacillary } \\
\text { Erysipelas, } \\
\text { Food poisoning } \\
\text { Influenza } \\
\text { Lethargic encephalitis } . . .\end{array}$ & $\begin{array}{r}6 \\
36 \\
14 \\
15 \\
8 \\
1 \\
2\end{array}$ & \begin{tabular}{|r|}
2 \\
1 \\
1
\end{tabular} & $\begin{array}{l}\text { Malaria } \\
\text { Poliomyelitis } \\
\text { Puerperal fever... } \\
\text { Scarlet fever } \\
\text { Tetanus. } \\
\text { Tuberculosis (all forms) } \\
\text { Typhoid fever......... }\end{array}$ & $\begin{array}{r}1 \\
161 \\
7 \\
62 \\
6 \\
167 \\
15\end{array}$ & {$[-\cdots$} \\
\hline
\end{tabular}

\section{NORWAY}

Notifiable diseases-November 1947.-Certain notifiable diseases were reported in Norway as follows:

\begin{tabular}{|c|c|c|c|}
\hline Disease & Cases & Disease & Cases \\
\hline $\begin{array}{l}\text { Cerebrospinal meningitis. } \\
\text { Diphtheria. } \\
\text { Dysentery } \\
\text { Encephalitis, epidemic. } \\
\text { Erysipelas } \\
\text { Gastroenteritis... } \\
\text { Gonorrhea } \\
\text { Hepatitis, epidemic } \\
\text { Impetigo contagioss } \\
\text { Infuenza. } \\
\text { Laryngitis, including bronchitis. } \\
\text { Malaria. }\end{array}$ & $\begin{array}{r}11 \\
68 \\
19 \\
1 \\
465 \\
2,742 \\
569 \\
234 \\
4,162 \\
2,376 \\
10,468 \\
1\end{array}$ & $\begin{array}{l}\text { Measles. } \\
\text { Mumps } \\
\text { Paratyphoid fever } \\
\text { Pneumonia (all forms) } \\
\text { Poliomyelitis } \\
\text { Rheumatic fever } \\
\text { Scabies } \\
\text { Scarlet fever } \\
\text { Syphilis } \\
\text { Tuberculosis (ail forms) } \\
\text { Weil's disease. } \\
\text { Whooping cough. }\end{array}$ & $\begin{array}{r}58 \\
1,868 \\
2 \\
1,612 \\
29 \\
147 \\
4,090 \\
405 \\
116 \\
481 \\
2 \\
479\end{array}$ \\
\hline
\end{tabular}




\section{REPORTS OF CHOLERA, PLAGUE, SMALLPOX, TYPHUS FEVER, AND YELLOW FEVER RECEIVED DURING THE CURRENT WEEK}

Nors.- Except in cases of unusual incidence, only those places are included which had not previously reported any of the above-named diseases, except yellow fever, during recent months. All reports of yellow fever are published currently.

A table showing the accumulated figures for these diseases for the year to date is published in the PUBLIC HEALTH REPORTs for the last Friday of each month.

\section{Plague}

Ecuador-Loja Province-Paltas County.-During the week ended January 24, 1948, 1 case of plague was reported in Paltas County, Loja Province, Ecuador.

Siam (Thailand).--Plague has been reported in Siam as follows: Weeks ended-January 31, 1948, 3 cases were reported near the Burma border; February 7, 1948, 16 cases with 7 deaths were reported, including 10 cases with 4 deaths in the extreme northern portion of Siam.

\section{Smallpox}

British East Africa-Uganda.-For the week ended January 24, 1948,39 cases of smallpox were reported in Uganda, British East Africa.

China-Foochow.-For the period January 11-20, 1948, 52 cases of smallpox were reported in Foochow, China.

Siam (Thailand).-Smallpox has been reported in Siam as follows: Weeks ended - January 31, 1948, 67 cases with 7 deaths, including 24 cases in Bangkok and 8 cases in Dhonburi; February 7, 1948, 70 cases with 2 deaths, including 28 cases in Bangkok and 8 cases in Dhonburi.

Venezuela-Puerto La Cruz.-According to information dated February 27, 1948, 41 cases of smallpox (alastrim) had occurred in Puerto La Cruz, Venezuela.

\section{DEATHS DURING WEEK ENDED FEB. 21, 1948}

[From the Weekly Mortality Index, issued by the National Office of Vital Statistics]

\begin{tabular}{|c|c|c|}
\hline & $\begin{array}{l}\text { Week ended } \\
\text { Feb. 21, } 1948\end{array}$ & $\begin{array}{c}\text { Correspond- } \\
\text { ing week, } \\
1947\end{array}$ \\
\hline $\begin{array}{l}\text { Data for } 93 \text { large cities of the United States: } \\
\text { Total deaths } \\
\text { Median for } 3 \text { prior years } \\
\text { Total deaths, first } 8 \text { weeks of year } \\
\text { Deaths under } 1 \text { year of age } \\
\text { Median for } 3 \text { prior years } \\
\text { Deaths under } 1 \text { year of age, first } 8 \text { weeks of year } \\
\text { Data from industrial insurance companies: } \\
\text { Policies in force } \\
\text { Number of death chaims } \\
\text { Death claims per } 1,000 \text { policies in force, annual rate } \\
\text { Death claims per } 1,000 \text { policies, first } 8 \text { weeks of year, annual rate. }\end{array}$ & $\begin{array}{r}10,655 \\
9,474 \\
83,951 \\
776 \\
594 \\
5.816 \\
66,865,709 \\
14,490 \\
11.3 \\
10.2\end{array}$ & $\begin{array}{r}9,741 \\
79,778 \\
7785 \\
6,581 \\
67,313,401 \\
13,317 \\
10.3 \\
9.7\end{array}$ \\
\hline
\end{tabular}




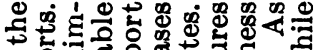
5 管

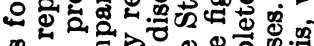

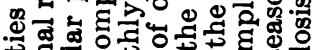

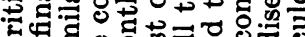
ว

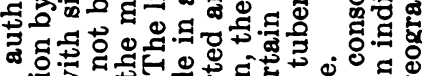
今. ฮె口 궁 \& 웅

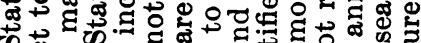
क

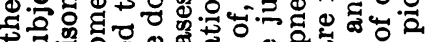

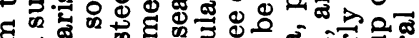
응

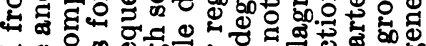
o $0 \%$ 연

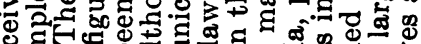
\&

ᄀ 40 \%

9 क

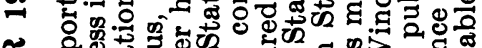

4

순 (200

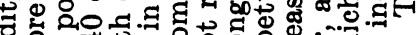

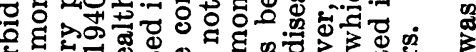
\% द

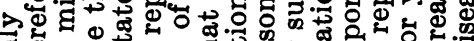

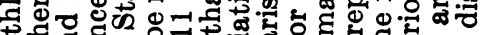
च 연

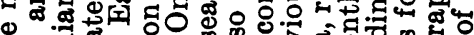
o † 4 o o 뚜영 ส 0 융. \%

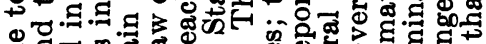

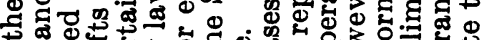

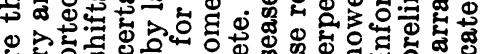

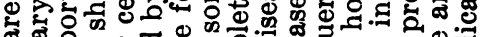

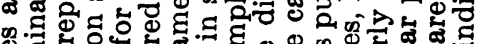
\%

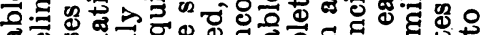
\$ so 0 o 急 就 엉

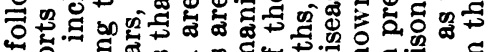

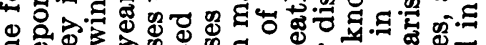
†

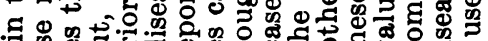
.

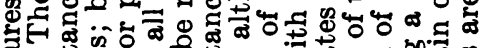

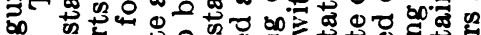

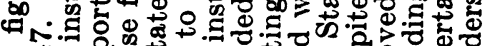

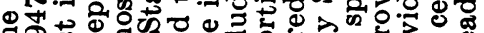

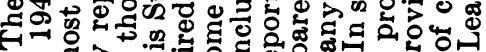

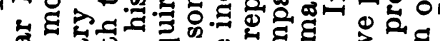

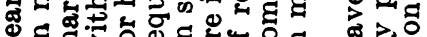

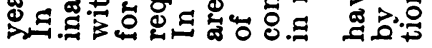

\begin{tabular}{|c|c|c|c|}
\hline 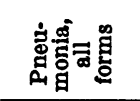 & : & 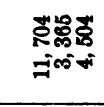 & 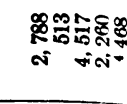 \\
\hline 递忽 & & $\begin{array}{ll}\infty \\
\vdots \\
\vdots\end{array}$ & \\
\hline 言蓠苟 & 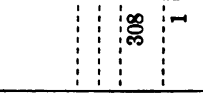 & 808 & 骂 \\
\hline 兽 & 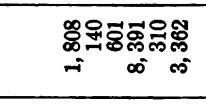 & 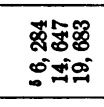 & 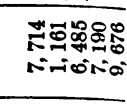 \\
\hline 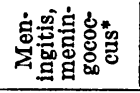 & ఇనค1 & 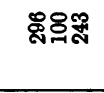 & 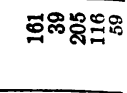 \\
\hline 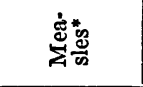 & 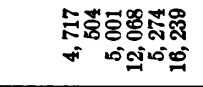 & 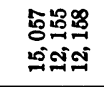 & 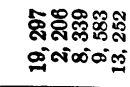 \\
\hline 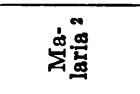 & מ্: & : & 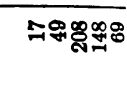 \\
\hline 㻤营 & ஜస్లి్స: & 옹욤ำ & 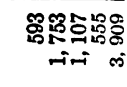 \\
\hline 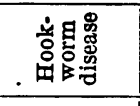 & $\begin{array}{l:l}-1 & \\
-1 & \end{array}$ & $\stackrel{5}{\circ}$ & \\
\hline 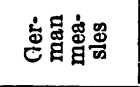 & 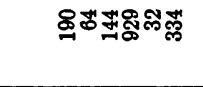 & 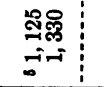 & 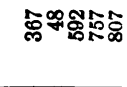 \\
\hline 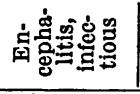 & $\infty \rightarrow x^{\infty}-\infty$ & $\$+\infty$ & 7ஜిలం \\
\hline 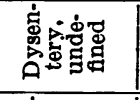 & & $\begin{array}{l:l}\infty \\
\end{array}$ & $8 \pi$ \\
\hline 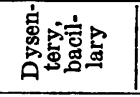 & N- & 어요 & 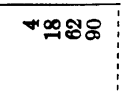 \\
\hline 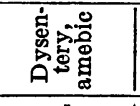 & N- & 쥬ำ & 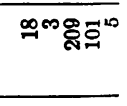 \\
\hline 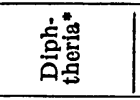 & 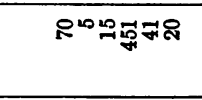 & 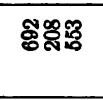 & 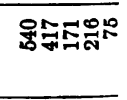 \\
\hline 宕言总 & 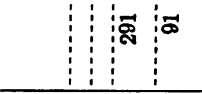 & $\Rightarrow$ & 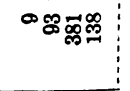 \\
\hline 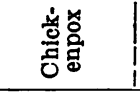 & 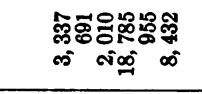 & 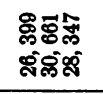 & 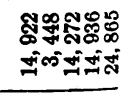 \\
\hline 送总 & 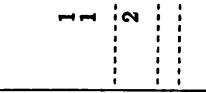 & "ूक & \\
\hline 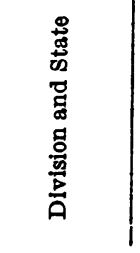 & 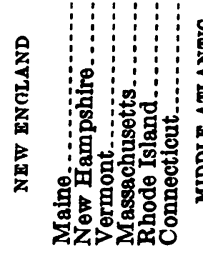 & 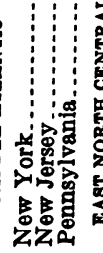 & 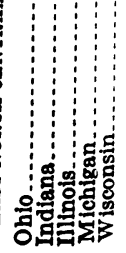 \\
\hline
\end{tabular}




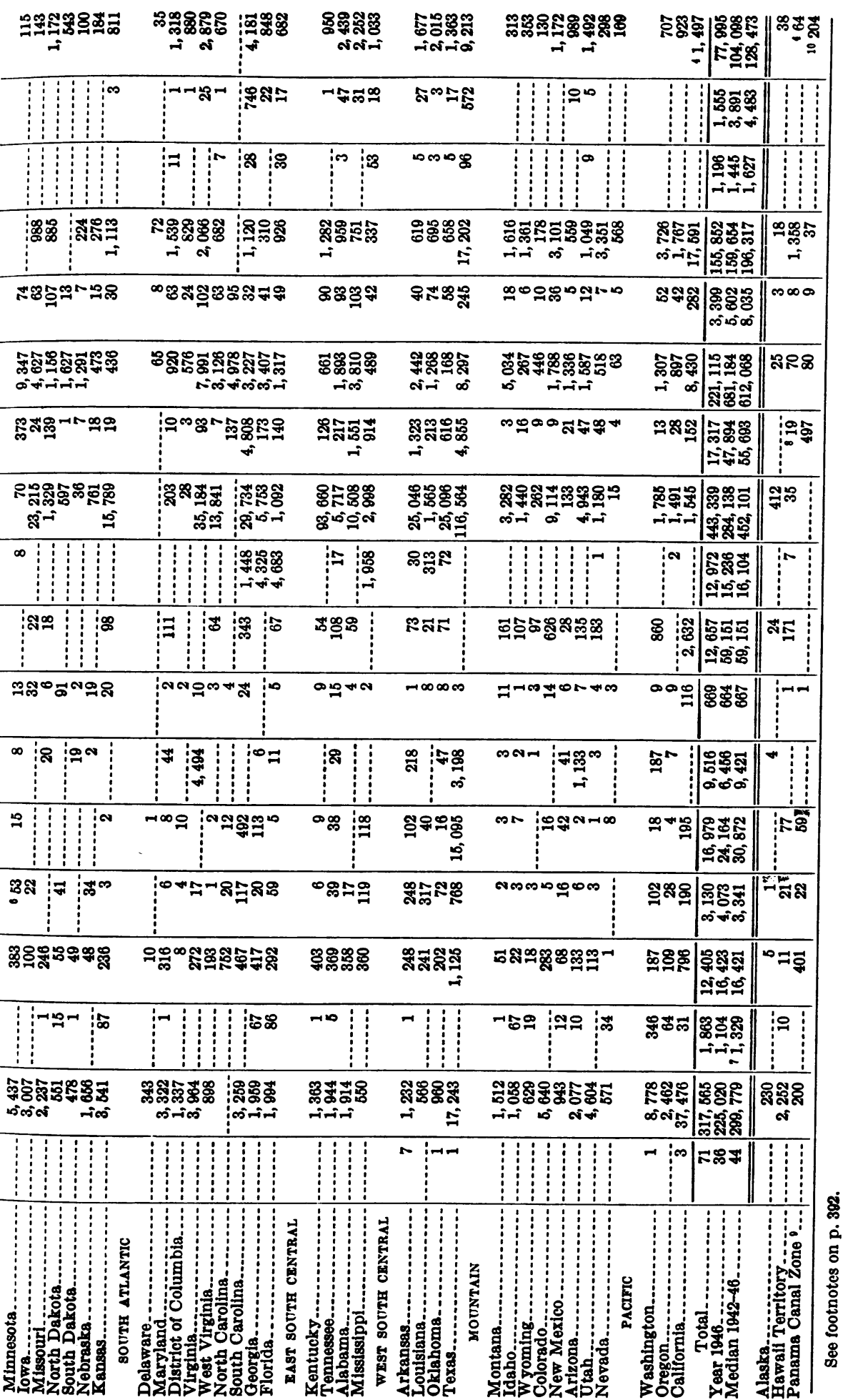




\begin{tabular}{|c|c|c|c|c|c|}
\hline 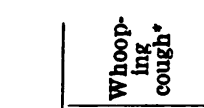 & 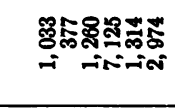 & 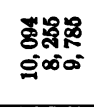 & 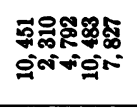 & 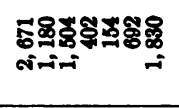 & 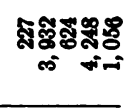 \\
\hline 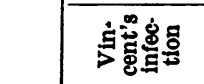 & $\begin{array}{l:l} & \infty \\
& \infty\end{array}$ & & 요저읓 & \begin{tabular}{l:l:l}
$\infty$ & $\infty$ \\
\hdashline & & 0
\end{tabular} & in \\
\hline 总葛总 & 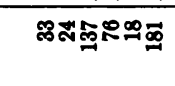 & శ్హి\$ః & 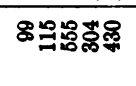 & 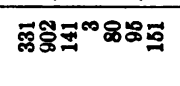 & N: \\
\hline 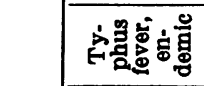 & $\vdots-1$ & \begin{tabular}{l:l}
$\infty$ & 0 \\
\hdashline
\end{tabular} & ザールN & & : \\
\hline ま & $\infty \rightarrow \infty \mathbb{p}^{\infty}$ & ส99 & $\begin{array}{l} \pm 009- \\
==\end{array}$ & 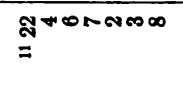 & 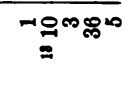 \\
\hline 它㻤 & 윰유메 & \&్తి? & 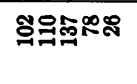 & 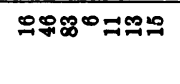 & 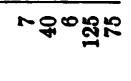 \\
\hline 弯葛 & & $\infty \infty \infty$ & 여명 & NN⿱亠凶禸: & \\
\hline 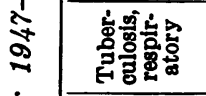 & 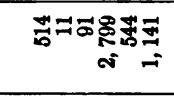 & 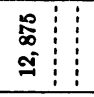 & 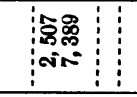 & 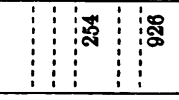 & 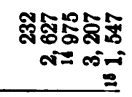 \\
\hline 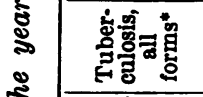 & 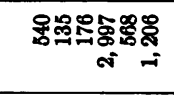 & 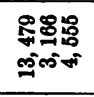 & 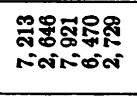 & 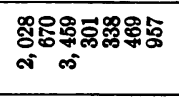 & 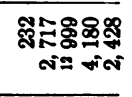 \\
\hline 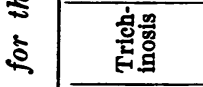 & $\infty$ : & ஐำ & mant & : & a \\
\hline 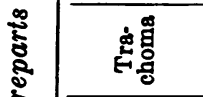 & :- & $\begin{array}{l:l}-1 \\
-1\end{array}$ & $\infty \begin{array}{c:c}\infty & 0-\infty \\
& \end{array}$ & N: & -1 \\
\hline 蜜高 & ๓ー & $\infty+\infty$ & มีニสิล & \begin{tabular}{r|}
$*+\infty$ \\
$\vdots$ \\
$\vdots$
\end{tabular} & $\begin{array}{l:l}\infty & \infty \\
& \end{array}$ \\
\hline 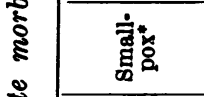 & & มี- & ఇజ్ & ーNニザー゙のற & 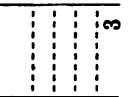 \\
\hline 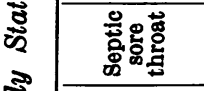 & 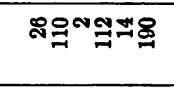 & 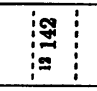 & 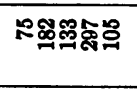 & 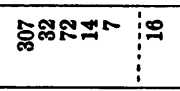 & ro \\
\hline 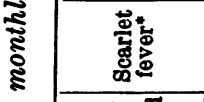 & 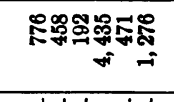 & 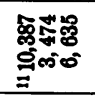 & 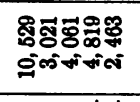 & 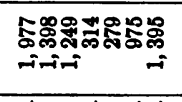 & 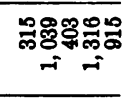 \\
\hline 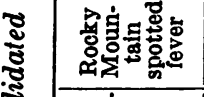 & $\begin{array}{llll}1 & 1 & 1 \\
\end{array}$ & ్తిสำ & تజ⿱ & 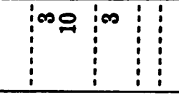 & ogntón \\
\hline 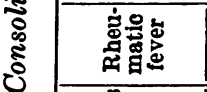 & $\begin{array}{l:l:l} & \vdots & 0 \\
& & 0 \\
\vdots & & \\
\end{array}$ & $\begin{array}{l:l}0 \\
\vdots \\
\vdots\end{array}$ & ஐー® & $\dddot{0}^{\infty}$ & : \\
\hline 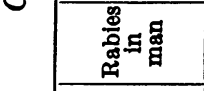 & & : & 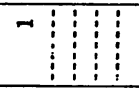 & 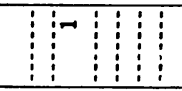 & 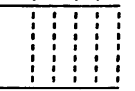 \\
\hline 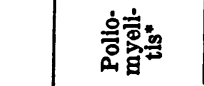 & 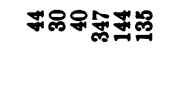 & 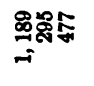 & 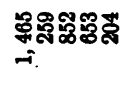 & 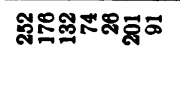 & 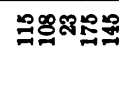 \\
\hline
\end{tabular}




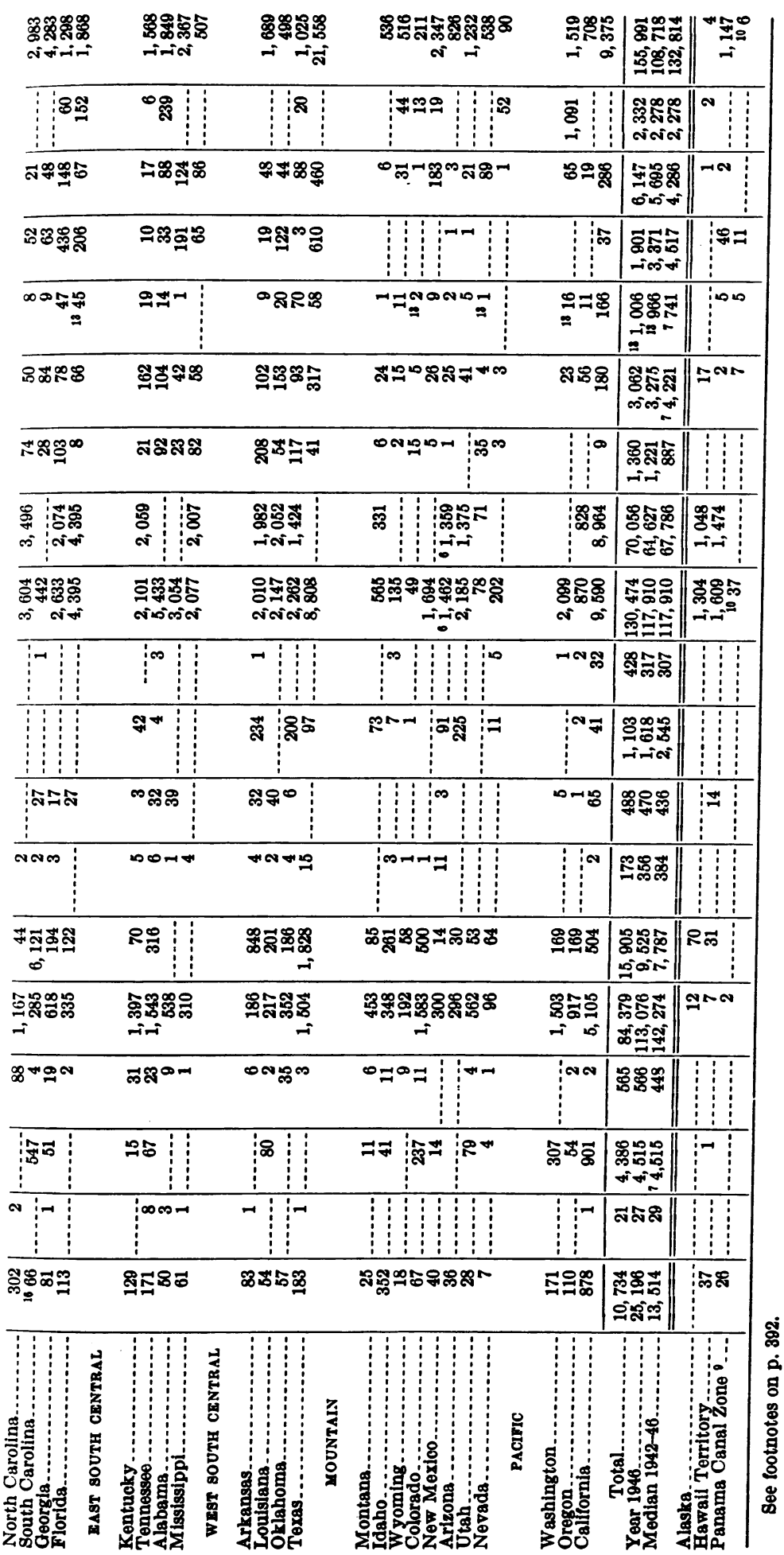




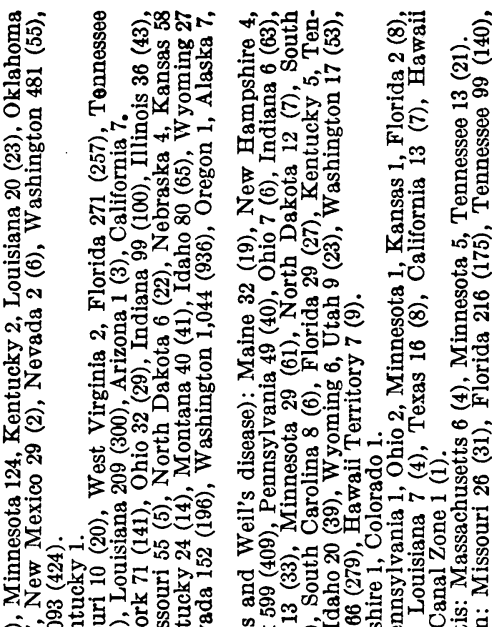

0 कृ

H o

政

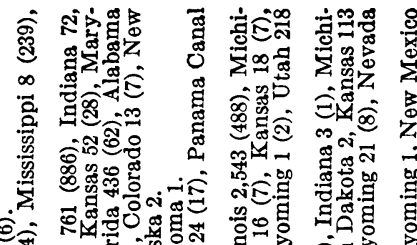

娄

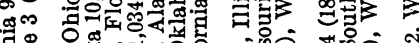

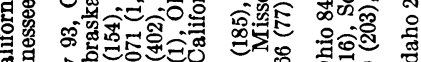

每

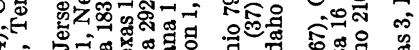

色

AN

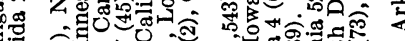

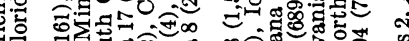

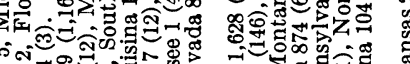

원 융

年

z

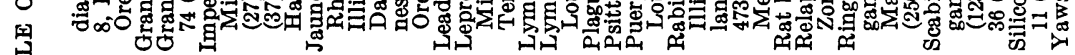

\section{.}

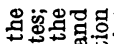

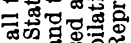

포영

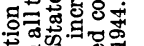

․․워

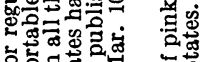

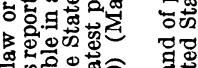

包芯

a

웡

⿷匚:응.

政

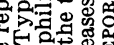

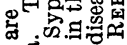

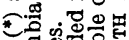

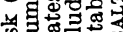

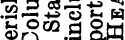

⿷匚

⿷匚⿳亠口冋.

s.

Вิ

용.․ㅕㅝ

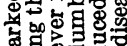

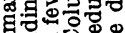

通

马:00

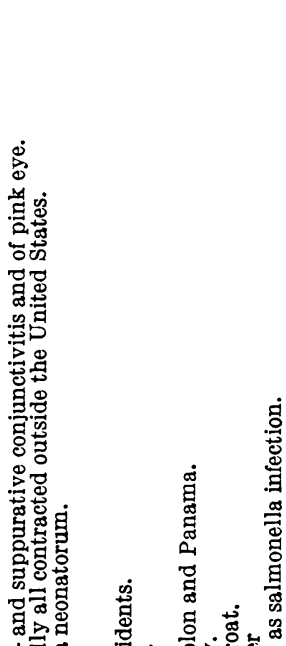

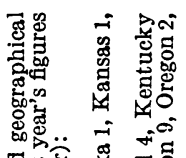

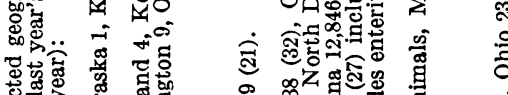

定

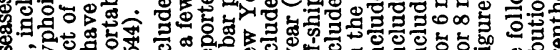
क

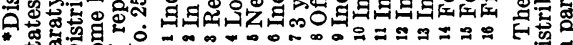

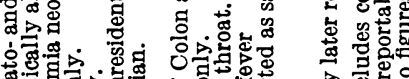

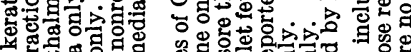
년.

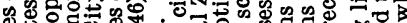

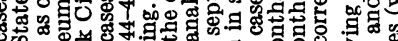

要

क范

鹿

ì

원

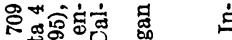

空空

0 . (1)

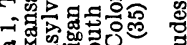

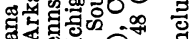
党

递

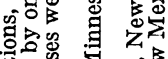

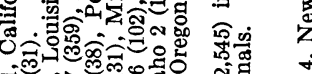

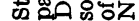




\section{EXAMINATION FOR REGULAR CORPS}

\section{United States Public Health Service}

A competitive examination for appointment in the Regular Corps of the United States Public Health Service in the grade of assistant surgeon (first lieutenant) and senior assistant surgeon (captain) will be held in April. The written examination will be conducted on April 5, 6, and 7 at places convenient to the candidate. Applicants who have passed the national board examinations may substitute the results for the written portion of the examination. The oral examination will be held at various points throughout the country.

All applicants must be at least 21 years of age and citizens of the United States, must present a diploma of graduation from a recognized medical school, and satisfactorily pass a physical examination performed by Public Health Service officers.

Applicants for the grade of assistant surgeon must have had at least 7 years of educational and professional training or experience, exclusive of high school. Applicants for the grade of senior assistant surgeon must have had at least 11 years of educational and professional training or experience, exclusive of high school.

Entrance pay for an assistant surgeon with dependents is $\$ 5,011$ a year and for senior assistant surgeon with dependents $\$ 5,551$ a year. This includes the additional pay of $\$ 1,200$ for medical officers, as well as subsistence and rental allowance. Provisions are made for promotions at regular intervals up to and including the grade of senior surgeon (lieutenant colonel) and for selection for promotion to grade of medical director (colonel) at $\$ 9,751$ a year. Retirement is authorized at either completion of 30 years' service or at age of 64 . Full medical care including disability retirement at three-fourths pay is provided.

Application forms may be obtained from Public Health Service Hospitals, District Offices or by writing to the Surgeon General, United States Public Health Service, Washington 25, D. C. 